\title{
Self-Replicating RNA Viruses for Vaccine Development against Infectious Diseases and Cancer
}

\author{
Kenneth Lundstrom
}

check for

updates

Citation: Lundstrom, K. Self-Replicating RNA Viruses for Vaccine Development against Infectious Diseases and Cancer. Vaccines 2021, 9, 1187. https:/ / doi.org/10.3390/vaccines9101187

Academic Editors: Ângela Maria Almeida de Sousa, Christiane Pienna Soares, Aldo Venuti and François Meurens

Received: 16 August 2021

Accepted: 12 October 2021

Published: 15 October 2021

Publisher's Note: MDPI stays neutral with regard to jurisdictional claims in published maps and institutional affiliations.

Copyright: (C) 2021 by the author. Licensee MDPI, Basel, Switzerland. This article is an open access article distributed under the terms and conditions of the Creative Commons Attribution (CC BY) license (https:// creativecommons.org/licenses/by/ $4.0 /)$.
PanTherapeutics, 1095 Lutry, Switzerland; lundstromkenneth@gmail.com

\begin{abstract}
Alphaviruses, flaviviruses, measles viruses and rhabdoviruses are enveloped singlestranded RNA viruses, which have been engineered for recombinant protein expression and vaccine development. Due to the presence of RNA-dependent RNA polymerase activity, subgenomic RNA can replicate close to $10^{6}$ copies per cell for translation in the cytoplasm providing extreme transgene expression levels, which is why they are named self-replicating RNA viruses. Expression of surface proteins of pathogens causing infectious disease and tumor antigens provide the basis for vaccine development against infectious diseases and cancer. Self-replicating RNA viral vectors can be administered as replicon RNA at significantly lower doses than conventional mRNA, recombinant particles, or DNA plasmids. Self-replicating RNA viral vectors have been applied for vaccine development against influenza virus, HIV, hepatitis B virus, human papilloma virus, Ebola virus, etc., showing robust immune response and protection in animal models. Recently, paramyxovirus and rhabdovirus vector-based SARS-CoV-2 vaccines as well as RNA vaccines based on self-amplifying alphaviruses have been evaluated in clinical settings. Vaccines against various cancers such as brain, breast, lung, ovarian, prostate cancer and melanoma have also been developed. Clinical trials have shown good safety and target-specific immune responses. Ervebo, the VSV-based vaccine against Ebola virus disease has been approved for human use.
\end{abstract}

Keywords: self-replicating RNA viruses; vaccines; infectious diseases; cancer; immune response; tumor regression; protection; approval

\section{Introduction}

Vaccine development has always had a central position in prevention of infectious diseases, but with the onset of the COVID-19 pandemic it has reached unprecedented levels. Similarly, the area of cancer vaccines has drawn plenty of attention. Obviously, the development of vaccines against SARS-CoV-2 has been approached from every possible angle including inactivated and attenuated viruses, protein and peptide subunit-based vaccines, nucleic acid-based vaccines, and viral vectors [1]. In this review the focus will be on viral vectors. Although the strongest progress has been achieved for adenovirus vectors with Emergency Use Authorization (EUA) for the ChAdOx1 nCoV-19 [2], Ad26.COV2.S [3], and rAd26-S/rAd5-S [4], only vaccine candidates based on self-replicating RNA viruses will be described here. In addition to SARS-CoV-2, other viral pathogens such as influenza virus, human immunodeficiency virus (HIV), hepatitis B virus (HBV), human papilloma virus (HPV), Ebola virus (EBOV) and Lassa virus (LASV) have been targeted [5]. Selfreplicating RNA viruses have also been used for cancer vaccine development. In this review multiple examples of immunization with self-amplifying RNA viral vectors expressing various antigens against infectious agents and tumors are presented. The advantages and disadvantages of using self-replicating RNA viral vectors, especially RNA-based delivery, are also discussed.

\section{Self-Replicating RNA Viruses}

Application of self-replicating RNA viruses for vaccines against infectious diseases and cancer has clear advantages compared to other viral vectors and non-viral delivery 
systems. Self-replicating RNA viruses deposit their RNA directly into the cytoplasm of infected host cells [6], which requires no delivery to the nucleus as is the case for some other RNA viruses such as influenza virus, and also for DNA-based delivery. In the case of positive strand RNA viruses such as alphaviruses, the most significant feature relates to the efficient self-replication/amplification of delivered RNA by the established RNA replication complex, which can accumulate close to $10^{6}$ copies of subgenomic RNA per cell in the host cell cytoplasm [7]. It will generate high levels of antigen expression, which can potentially elicit superior immune responses and may also allow immunizations with smaller doses resulting in reduced adverse events. It can also provide extreme expression of toxic, anti-tumor and immunostimulatory genes for cancer vaccination and therapy. Additionally, self-replicating RNA viral vectors can be utilized as recombinant replicationdeficient viral particles, replicon RNA, or layered DNA/RNA vectors (Figure 1). Another feature of interest is the transient nature of high levels of transgene expression provided by self-replicating RNA viruses due to the degradation of RNA transcribed from recombinant particles and RNA replicons within 5-7 days post-immunization. It is advantageous for vaccine development against both infectious diseases and cancers. Furthermore, in contrast to for instance retroviruses, alphavirus RNA is not subjected to reverse transcription and integration into the host genome.

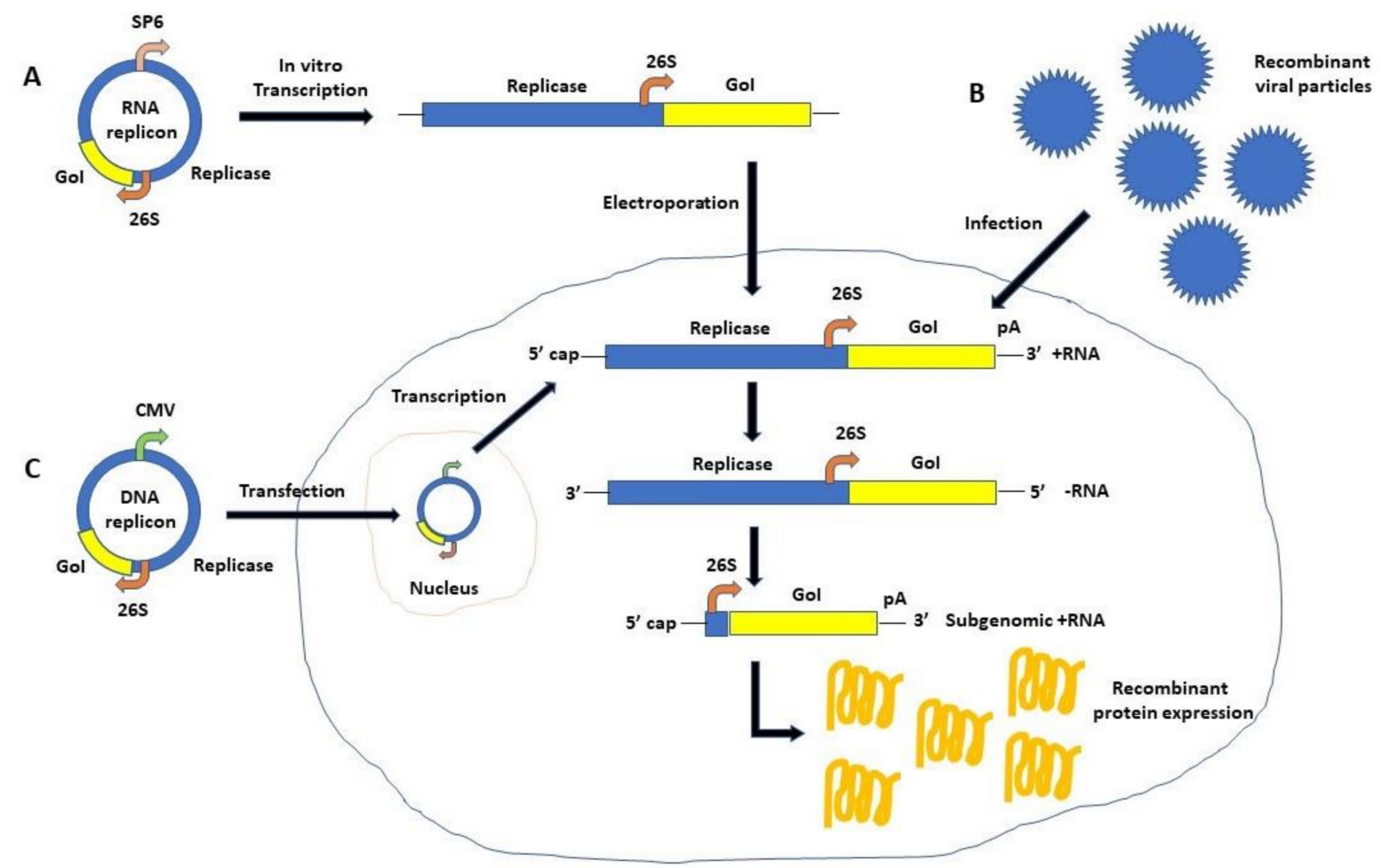

Figure 1. Schematic illustration of self-replicating RNA alphavirus-based expression systems. Alphavirus-based delivery and expression systems comprise of infection of recombinant viral particles, electroporation/lipid-based transfection of in vitro transcribed RNA or transfection of plasmid DNA. Recombinant protein expression can be obtained as follows. In vitro transcribed RNA carrying the replicase gene and the gene of interest is electroporated/transfected into mammalian host cells (A). Alternatively, the replicon RNA can be delivered to host cells by infection with recombinant alphavirus particles (B). The third option is to transfect alphavirus DNA replicons (C), which after DNA delivery to the nucleus RNA is in vivo transcribed. The replicase complex will amplify RNA molecules (self-replication) and recombinant protein will be expressed from the $26 \mathrm{~S}$ subgenomic promoter. $5^{\prime}$ cap, $5^{\prime}$ end cap analogue; $26 \mathrm{~S}$, alphavirus subgenomic promoter; $\mathrm{CMV}$, cytomegalovirus promoter; GoI, gene of interest; pA, poly A signal; SP6, bacteriophage SP6 RNA polymerase promoter. 
Self-replicating RNA viruses can be divided into two groups based on the polarity of their RNA genome. All self-replicating RNA viruses possess a single-stranded nonfragmented RNA (ssRNA) genome. However, alphaviruses [6] and flaviviruses [8] have a positive-sense RNA genome, whereas the genome of paramyxoviruses [9] and rhabdoviruses [10] is of negative polarity. The difference in polarity has consequences for their applications as the positive sense ssRNA is immediately after infection translated in the cytoplasm. In the case of alphaviruses, expression systems are based on delivery of recombinant viral particles, RNA replicons or plasmid DNA replicons. Infection with recombinant particles and electroporation or lipid-based transfection of in vitro transcribed replicon RNA deliver positive sense ssRNA to the cytoplasm of host cells. Utilization of plasmid DNA transfection requires initial delivery of DNA to the nucleus followed by in vivo transcription of RNA. The recombinant RNA containing the non-structural replicase genes and the gene of interest (GoI) is efficiently amplified (self-replication) from a minus strand RNA template and translation of recombinant protein coding for the GoI occurs in the cytoplasm. A schematic illustration of alphavirus self-replicating expression systems is presented in Figure 1. The most prominent alphavirus expression systems are based on Semliki Forest virus (SFV) [11], Sindbis virus (SIN) [12] and Venezuelan equine encephalitis virus (VEEV) [13]. Flavivirus expression systems have been engineered for Kunjin virus (KUN), where the gene of interest is introduced between the first 60 nucleotides of the C20 core protein and the last 22 codons of the E22 envelope protein [14]. The GoI is expressed as part of a larger polyprotein from which the flanking regions are cleaved off by the FMDV$2 \mathrm{~A}$ protease sequence in the KUN vector [15]. KUN production has been facilitated by the engineering of a packaging cell line [16]. In addition to KUN, expression vectors have been engineered for West Nile virus (WNV) [17], yellow fever virus (YFV) [18], Dengue virus (DENV) [19], and tick-borne encephalitis virus (TBEV) [20]. Furthermore, the bovine viral diarrhea virus (BVDV) has been engineered as an expression vector by introducing the GFP reporter gene between the N(pro) and C genes of the non-cytopathic type-1 BVDV strain SD1 [21]. Similarly, expression of GFP from a bicistronic classical swine fever virus (CSFV) in infected host cells confirmed the potential of CSFV as an expression vector [22].

In the case of RNA viruses with negative ssRNA polarity such as vesicular stomatitis virus (VSV), the RNA-dependent RNA polymerase (RdRp) responsible for self-replication is encoded in the $\mathrm{L}$ gene and the phosphoprotein $(\mathrm{P})$ is an essential cofactor for the $\mathrm{RdRp}$ activity. In the case of VSV expression systems, the VSV glycoprotein $(\mathrm{G})$ gene is generally replaced by the GoI or the GoI is inserted between the $\mathrm{G}$ and $\mathrm{L}$ genes for the generation of either pseudotype or recombinant VSV particles (Figure 2A) [23,24]. Pseudotype VSV can be produced in mammalian cells by transfection of plasmid DNA containing foreign envelope genes followed by infection with the VSV G-complemented G-VSV $\Delta$ G pseudotype virus. The generated pseudotype VSV can infect target cells, but do not produce infectious viral progeny. In contrast, infection of mammalian producer cells with VSV G-complemented recombinant virus replacing the VSV G with a foreign envelope generates fully infectious viral progeny [24]. Originally, application of reverse genetics for expression vector engineering was based on recombinant vaccinia virus vectors. In the case of VSV, the nucleoprotein $(\mathrm{N})$, phosphoprotein $(\mathrm{P})$, polymerase $(\mathrm{L})$ and the full-length antigenomic RNA were expressed from four plasmids under the control of the T7 promoter from a vaccinia virus [25]. To develop a vaccinia virus-free system, the VSV N, P and L genes were introduced downstream of both the T7 promoter and an internal ribosomal entry site (IRES) and the T7 polymerase was provided by the BSR-T7/5 stable cell line. The elimination of the vaccinia virus from the reverse genetics system presented an attractive alternative for generation of infectious VSV from DNA.

In the case of rabies virus (RABV), the GoI can be inserted between the $\mathrm{N}$ and $\mathrm{P}$ genes and $G$ and $L$ (Figure 2B) [26,27]. A vaccinia virus-free reverse genetics system has also been engineered for RABV [28]. For paramyxoviruses, measles virus (MV) vectors, packaging systems and helper cell lines have been engineered to allow rescue of replicating MV from plasmid DNA vectors $[29,30]$. Generally, the GoI is inserted between the phosphoprotein 
$(\mathrm{P})$ and the matrix protein $(\mathrm{M})$ or alternatively between the hemagglutinin (HA) gene and the large protein (L) (Figure 2C). As a comparison of positive and negative strand RNA viruses, their replication strategies are illustrated in Figure 3.

A

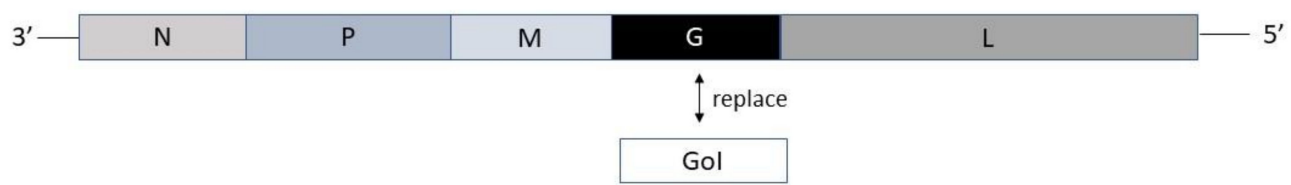

B

\begin{tabular}{|c|c|c|c|c|c|}
\hline $\mathrm{N}$ & Gol & $P$ & $M$ & G & L \\
\hline $\mathrm{N}$ & $P$ & $M$ & G & Gol & L \\
\hline
\end{tabular}

C

\begin{tabular}{|c|c|c|c|c|c|c|c|}
\hline $\mathrm{N}$ & $P$ & Gol & $M$ & $\mathrm{Fu}$ & $\mathrm{H}$ & L & T7T \\
\hline $\mathrm{N}$ & $P$ & $\mathrm{M}$ & $\mathrm{Fu}$ & $\mathrm{H}$ & Gol & L & T7T \\
\hline
\end{tabular}

$\mathrm{T7}$

$\mathrm{CMV}$

Figure 2. Self-replicating RNA viral vectors of negative polarity. (A) VSV vector for replacement of VSV G protein. (B) Rabies virus and (C). Measles virus expression vectors. CMV, cytomegalovirus promoter; Fu, fusion protein, G, glycoprotein; GoI, gene of interest; H, hemagglutinin; L, large protein; M, matrix protein; P. phosphoprotein; T7, T7 RNA polymerase promoter; T7T, T7 terminal sequence.
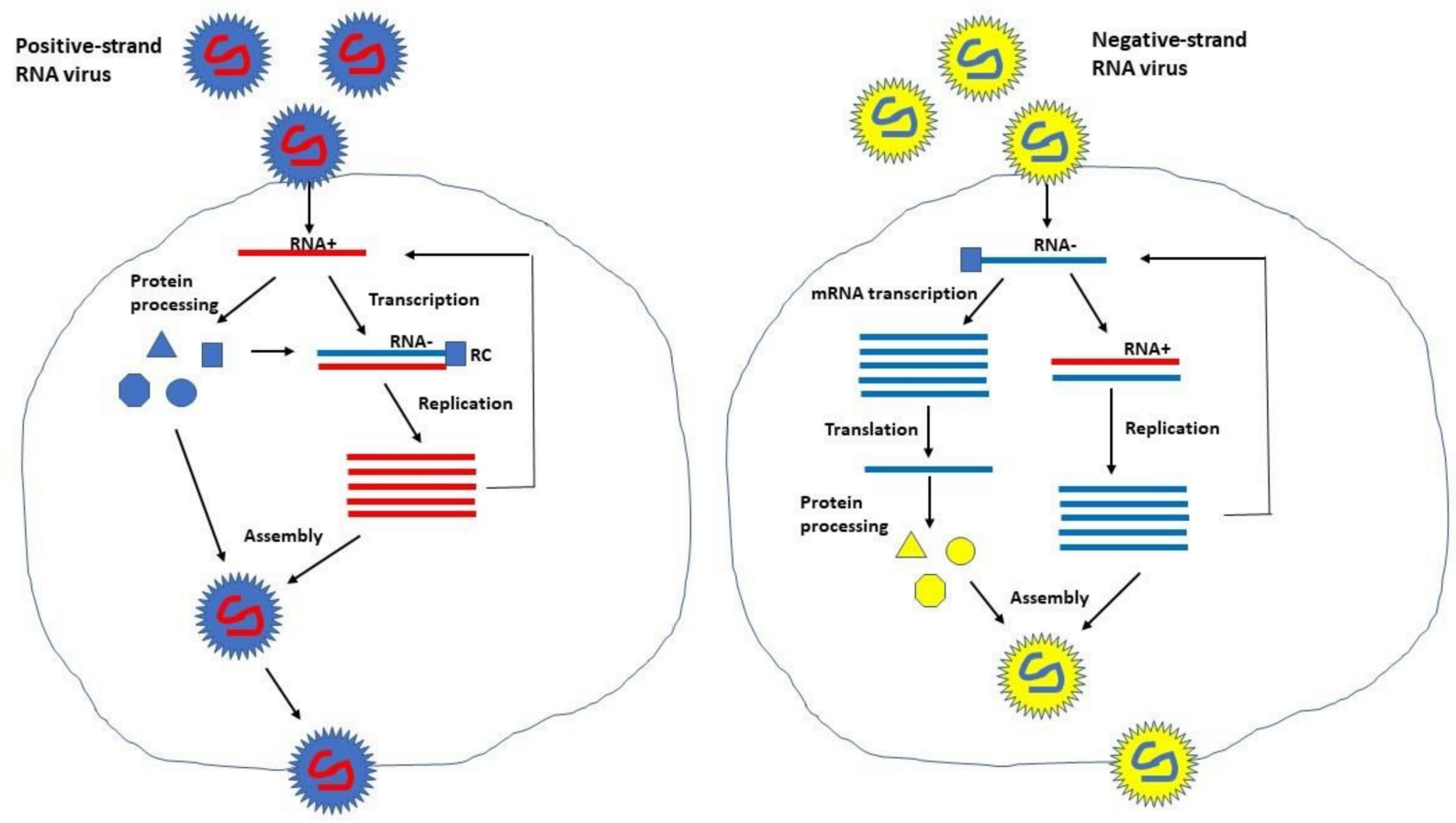

Figure 3. Replication strategy of positive- and negative-strand self-replicating RNA viruses. For positive-strand RNA viruses, the viral RNA is directly translated in the cytoplasm and replication of new positive-strand RNA copies require transcription of a negative-strand RNA template. In contrast, negative-strand RNA viruses rely on mRNA transcription before translation can take place. 


\section{Infectious Diseases}

The classic approach for targeting of infectious diseases for vaccine development has comprised overexpression of immunogenic surface epitopes or proteins as antigens, which elicit immune responses leading to protection against challenges with lethal doses of pathogens [31]. A large number of preclinical and some clinical studies have been conducted for vaccine candidates based on self-replicating RNA viral vectors and it is only possible to provide some examples below and in Tables 1 and 2. The most common targets have been viral infections, but additionally vaccine candidates against bacterial infections and tropical diseases have been developed.

Table 1. Examples of preclinical studies on self-replicating RNA viral vector vaccines against infectious diseases.

\begin{tabular}{|c|c|c|c|c|}
\hline Virus/Disease & Antigen & Vector & Findings & Ref. \\
\hline \multicolumn{5}{|l|}{ Alphaviruses } \\
\hline CHIKV/CHIK & E3-E2-6K-E1 & Chimeric VSV-Env & Protection against $\mathrm{CHIKV}$ in mice & [32] \\
\hline VEEV/VEE & E3-E2-6K-E1 & VEEV-Env & Protection against VEE in mice, macaques & [33] \\
\hline WEEV/WEE & E3-E2-6K-E1 & WEEV-Env & Partial protection in macaques, strong in mice & [33] \\
\hline $\mathrm{EEEV} / \mathrm{EEE}$ & E3-E2-6K-E1 & EEEV-Env & Protection against EEE in mice, macaques & [33] \\
\hline VEEV/VEE & V4020 strain & VEEV DNA & Protection against VEE in mice & [34] \\
\hline VEEV/VEE & V4020 strain & VEEV DNA & Protection against VEE in macaques & {$[35]$} \\
\hline CHIKV/CHIK & C, Env & MV-CHIKV VLPs & Protection against $\mathrm{CHIKV}$ in macaques & [36] \\
\hline \multicolumn{5}{|l|}{ Arenaviruses } \\
\hline LASV/LHF & GPC & VSV-GPC & Protection in guinea pigs and macaques & [37] \\
\hline LASV/LHF & GPC & MV-LASV-GPC & Protection against LASV in macaques & [38] \\
\hline $\mathrm{LASV} / \mathrm{LHF}$ & GPC & YFV-LASV GPC & $80 \%$ protection in guinea pigs, vector instability & [39] \\
\hline LASV/LHF & GPC G1/G2 & YFV-LASV G1 + G2 & $83 \%$ protection in guinea pigs, stable vector & [40] \\
\hline LASV/LHF & GPC G1/G2 & YFV-LASV G1 + G2 & No protection in marmosets & [41] \\
\hline $\mathrm{LASV} / \mathrm{LHF}$ & GPC or NP & VEEV-GPC/NP & Protection in guinea pigs after 3 immunizations & [42] \\
\hline $\mathrm{LASV} / \mathrm{LHF}$ & GPC & Multivalent VEEV & Protection in inbred CBA/J mice & [43] \\
\hline JUNV / AHF & GPC & VEEV-GPC & Protection against JUNV in mice & [44] \\
\hline $\mathrm{MACV} / \mathrm{BHF}$ & GPC & VEEV-GPC & Protection against MACV in mice & {$[44]$} \\
\hline \multicolumn{5}{|l|}{ Filoviruses } \\
\hline EBOV/EVD & GP D637L & KUN-GP D637L & Protection in $75 \%$ of nonhuman primates & [45] \\
\hline $\mathrm{EBOV} / \mathrm{EVD}$ & GP & VSV-GP & Protection against two EBOV strain in macaques & {$[46,47]$} \\
\hline MARV/MHF & GP & VSV-GP & Protection against MARV in macaques & [48] \\
\hline SUDV/EVD & GP & VEEV-GP & Protection against SUDV and EBOV in macaques & [48] \\
\hline \multicolumn{5}{|l|}{ Flaviviruses } \\
\hline $\mathrm{DENV} / \mathrm{DF}$ & E85 & VEEV-E85 & Protection against DENV in mice & [49] \\
\hline $\mathrm{DENV} / \mathrm{DF}$ & ED3 & MV-ED3 & Strong immunogenicity, partial protection in mice & {$[50]$} \\
\hline $\mathrm{DENV} / \mathrm{DF}$ & Tetravalent DENV & YFV (CYD-TDV) & Good safety, immunogenicity in rodents, primates & {$[51,52]$} \\
\hline $\mathrm{DENV} / \mathrm{DF}$ & Tetravalent DENV & YFV (CYD-TDV) & Approved vaccine for endemic populations & [53] \\
\hline $\mathrm{ZIKV} / \mathrm{ZVD}$ & prME & VEEV-NLC RNA & Protection in mice with $10 \mathrm{ng}$ of RNA & [54] \\
\hline ZIKV /ZVD & prME & $\begin{array}{c}\text { Chimeric } \\
\text { VSV-prME }\end{array}$ & Protection against ZIKV in mice & {$[32]$} \\
\hline ZIKV /ZVD & E-NS1 & VSV-E-NS1 & Protection against ZIKV in mice & [55] \\
\hline \multicolumn{5}{|l|}{ Hepatotropic } \\
\hline HBV/Hepatitis & HBsAg & MV-HBsAg & Protection against $\mathrm{HBV}$ in $50 \%$ of rhesus monkeys & [56] \\
\hline $\mathrm{HBV} /$ Hepatitis & MHB & SFV-MHB & Protection against HBV in mice & [57] \\
\hline $\mathrm{HBV} /$ Hepatitis & $\mathrm{HBcAg}$ & SFV-HBcAg & No protection against $\mathrm{HBV}$ in mice & [57] \\
\hline
\end{tabular}


Table 1. Cont.

\begin{tabular}{|c|c|c|c|c|}
\hline Virus/Disease & Antigen & Vector & Findings & Ref. \\
\hline \multicolumn{5}{|l|}{ Lentiviruses } \\
\hline $\mathrm{HIV} / \mathrm{AIDS}$ & HIV gp160 Env & MV-gp160 Env & Humoral and cellular immune responses in mice & [58] \\
\hline HIV / AIDS & HIV Env & SFV-Env & $\begin{array}{l}\text { Superior immunogenicity compared to immunization } \\
\text { with DNA and Env protein }\end{array}$ & [59] \\
\hline HIV / AIDS & HIV Env & SFV-Env RNA & Immune response in $75 \%$ of mice & [60] \\
\hline $\mathrm{HIV} / \mathrm{AIDS}$ & $\begin{array}{c}\text { HIV } \\
\text { Env/Gag/PolRT }\end{array}$ & SFV RPs/RNA & VLPs superior immunogenicity to RNA in mice & [61] \\
\hline HIV / AIDS & $\begin{array}{l}\text { HIV Env, } \\
\text { Gag/Pol/Nef }\end{array}$ & SFV DNA & Robust immune responses in mice & [62] \\
\hline HIV / AIDS & HIV gp140 & VEEV-RNA-CNE & Superior Ab response compared to VLPS in primates & [63] \\
\hline \multicolumn{5}{|l|}{ Influenza Viruses } \\
\hline IFVA/Influenza & HA & MV AIK-C-HA & Protection against influenza virus in cotton rats & [64] \\
\hline IFVA/Influenza & $\mathrm{HA}, \mathrm{NA}$ & VSV $\Delta G-H A / N A$ & Protection against influenza virus in mice & [65] \\
\hline IFVA/Influenza & HAfl & VSV-HAfl & Protection against influenza virus in mice & [66] \\
\hline IFVA/Influenza & HA & VEEV-HA & Protection in chickens & [67] \\
\hline IFVA/Influenza & HA & SFV-HA RNA & Protection in $90 \%$ of mice & [68] \\
\hline IFVA/Influenza & HA & VEEV-HA RNA & Protection in mice with 64-fold less RNA * & [69] \\
\hline IFVA/Influenza & M2e & SIN E2S1-M2e & Protection in mice & [70] \\
\hline IFVA/Influenza & $\mathrm{HA}, \mathrm{NP}$ & $\begin{array}{l}\text { CSFV-HA/NP } \\
\text { VRPs }\end{array}$ & Strong humoral and cellular response in pigs & [71] \\
\hline \multicolumn{5}{|l|}{ Coronaviruses } \\
\hline SARS-CoV/SARS & $S$ & VEEV-S & Protection against SARS-CoV in mice & [72] \\
\hline MERSCOV/MERS & $S$ & VSV $\Delta G-S$ & Neutralizing Abs and T cell responses in monkeys & [73] \\
\hline SARS-CoV-2/COV & $S$ & MV-S & Th1-biased $\mathrm{Ab}$ and $\mathrm{T}$ cell responses in mice & [74] \\
\hline SARS-CoV-2/COV & $\mathrm{S}$ & MV (TMV-083) & Phase I: weak immunogenicity, trial discontinued & $\begin{array}{l}{[75,} \\
76]\end{array}$ \\
\hline SARS-CoV-2/COV & $\mathrm{S}$ & VSV-S & Neutralizing Abs, protection in mice & [77] \\
\hline SARS-CoV-2/COV & $\mathrm{S}$ & VSV (V590) & Phase I: weak immunogenicity, trial discontinued & $\begin{array}{l}{[78,} \\
79]\end{array}$ \\
\hline SARS-CoV-2/COV & $\mathrm{S}$ & VSV $\Delta \mathrm{G}-\mathrm{S}$ & Protection against SARS-CoV-2 in hamsters & [80] \\
\hline SARS-CoV-2/COV & S & VSV $\Delta \mathrm{G}-\mathrm{S}$ & Phase I/II: study in progress & $\begin{array}{l}{[81,} \\
82]\end{array}$ \\
\hline PEDV /PED & $S$ fragment & BVDV & Neutralization of BVDV and PEDV in mice & [83] \\
\hline SARS-CoV-2/COV & $\mathrm{S}$ & LNP-VEEV-S RNA & Robust $\mathrm{Ab}$ responses in mice & [84] \\
\hline SARS-CoV-2/COV & $\mathrm{S}$ & LNP-VEEV-S RNA & Phase I/II: study in progress & [85] \\
\hline SARS-CoV-2/COV & $\mathrm{S}$ & $\begin{array}{l}\text { LUNAR-VEEV } \\
\text { RNA }\end{array}$ & Protection in mice after single dose & [86] \\
\hline SARS-CoV-2/COV & $\mathrm{S}$ & SIN-S $+\alpha \mathrm{OX} 40$ & Protection against SARS-CoV-2 in mice & [87] \\
\hline \multicolumn{5}{|l|}{ Bacterial } \\
\hline B. anthracis/Anthrax & PA & SIN-PA & Immune responses, some protection in mice & [88] \\
\hline B. abortus/Brucellosis & B. abortus IF3 & SFV-CS & Immune responses, protection in mice & [89] \\
\hline
\end{tabular}


Table 1. Cont

\begin{tabular}{|c|c|c|c|c|}
\hline Virus/Disease & Antigen & Vector & Findings & Ref. \\
\hline \multicolumn{5}{|l|}{ Parasitic } \\
\hline Plasmodium/Malaria & Pf332 antigen & SFV-Pf332 & Robust Th1-type immune response in mice & [90] \\
\hline Plasmodium/Malaria & $\begin{array}{c}\text { P. yoelii CS } \\
\text { epitope }\end{array}$ & SIN-CS & Protection against malaria in mice & {$[91]$} \\
\hline Leishmania/Leishmaniasis & $\begin{array}{l}\text { PpSP15- } \\
\text { LmSTI1 }\end{array}$ & $\begin{array}{c}\text { SFV-PpSP15- } \\
\text { LmSTI1 }\end{array}$ & Superior expression from replicon RNA & {$[92]$} \\
\hline
\end{tabular}

$\mathrm{OXX} 40$, immunostimulatory antibody; Ab, antibody; AHF, Argentine hemorrhagic fever; BHF, Bolivian hemorrhagic fever; BVDV, bovine viral diarrhea virus; C, capsid, CHIKV, Chikungunya virus; CNE, cationic nanoemulsion; COV, COVID-19 CS, circumsporozoite; DENV, Dengue virus; DF, Dengue fever; EBOV, Ebola virus; EEEV, eastern encephalitis virus; E85, DENV envelope ectodomain; ED3, DENV envelope protein domain III; Env, envelope proteins; EVD, Ebola virus disease; G1/G2; Glycoprotein subunit of GPC; GPC, glycoprotein complex; HA, hemagglutinin; HAfl, full-length HA; HBcAg, HBV core antigen; HBsAg, HBV surface antigen; HBV, hepatitis B virus; IFVA, influenza virus A; JUNV, Junin virus; LASV, Lassa virus; LHF, Lassa hemorrhagic fever; MACV, Machupo virus; MARV, Marburg virus; MERS-CoV, Middle East respiratory syndrome-coronavirus; MHB, middle HBV surface envelope glycoprotein; MHF, Marburg hemorrhagic fever; NA, neuraminidase; NP, nucleoprotein; NS1, nonstructural protein 1; PA, protective antigen; PEDV, porcine epidemic diarrhea virus; prME, membrane-envelope protein; RPs, recombinant particles; RSP, recombinant subviral particle; S, spike protein; SFV, Semliki Forest virus; VEEV, Venezuelan equine encephalitis virus; VLPs, virus-like particles; VSV, vesicular stomatitis virus; WEEV, western equine encephalitis virus; YFV, yellow fever virus; ZIKV, Zika virus; ZVD, Zika virus disease.* Compared to synthetic mRNA.

Among alphaviruses, Chikungunya virus (CHIKV) [93,94] and VEEV [95] have been responsible for epidemics in Africa, Polynesia, and South America. Vaccine development has included expression of the CHIKV envelope polyprotein E3-E2-6K-E1 from a chimeric VSV vector, which elicited neutralizing antibody responses and provided protection against CHIKV in mice after a single administration of $1 \times 10^{7} \mathrm{pfu}$ of VSV particles [32]. In another approach, expression vectors for VEEV, western equine encephalitis virus (WEEV), and eastern equine encephalitis (EEEV) were engineered by removing the furin cleavage site at the junction between the E2 and E3 envelope proteins [33]. It prevents the cleavage of the precursor p62 into E2 and E3 to produce infectious particles but generates replicationdeficient recombinant virus particles [33]. The combination of $1 \times 10^{7}$ IU of VEEV, WEEV, and EEEV or individual viral recombinant particles induced strong neutralizing antibody responses and protected mice from subcutaneous or aerosol challenges with VEEV, WEEV, and EEEV [33]. Similarly, immunization of cynomolgus macaques with $2 \times 10^{8} \mathrm{IU}$ of the VEEV-WEEV-EEEV combination elicited strong immune responses and protected against challenges with VEEV and EEEV. In contrast, the immune response against WEEV was weak and the protection against challenges with WEEV was only partial [33]. In the context of DNA-based delivery, the attenuated VEEV V4020 strain was administered to $\mathrm{BALB} / \mathrm{c}$ mice as a DNA/RNA layered replicon vector, which elicited robust neutralizing antibodies and protected mice from challenges with wildtype VEEV [34]. Protection against aerosol challenges with wildtype VEEV was also demonstrated in vaccinated cynomolgus macaques [35]. Furthermore, an MV-based vector expressing CHIKV capsid and envelope proteins showed strong immunogenicity and protection from viremia in macaques [36]. The MV-CHIKV VLP vaccine candidate was evaluated for safety and efficacy in a randomized, double-blind phase I clinical trial showing a seroconversion rate of $44-92 \%$ after a single dose, which reached $100 \%$ after a second immunization [96]. It was followed by a phase II study, which elicited strong neutralizing antibodies without causing any serious adverse events making it a promising CHIKV vaccine candidate [97].

Arenaviruses including such pathogens as LASV have also been targeted for vaccine development. In this context, VSV-based expression of the LASV glycoprotein complex (GPC) provided protection against LASV strains from Liberia, Mali, and Nigeria in guinea pigs and macaques immunized with $1 \times 10^{6}$ and $6 \times 10^{7} \mathrm{pfu}$, respectively [37]. MV-based GPC expression has also demonstrated protection in macaques after a single immunization with $6 \times 10^{6} \mathrm{pfu}$ of MV-GPC particles [38]. A randomized, placebo-controlled, dose-finding phase I trial is in progress in healthy volunteers receiving two doses of MV-LASV [98]. In another approach, the LASV GPC gene was introduced into the YFV vector between the envelope (E) and non-structural protein 1 (NS1) [39]. Immunization of guinea pigs was $80 \%$ 
protective, but due to instability of the full-length GPC, GP1 and GP2 subunit constructs were engineered in individual YFV vectors [40]. Combined immunization with YFV-LASV GP1 and -GP2 showed 83\% protection in guinea pigs with no stability issues. However, prime-boost vaccination of marmosets failed to provide protection confirming previous findings that robust immune responses and protection seen in rodents is not necessarily reproducible in non-human primates [41]. Expression of either LASV GPC or nucleoprotein (NP) from VEEV replicons protected guinea pigs from challenges with the LASV Josiah strain [42]. However, protection was only established after three immunizations with recombinant VEEV particles. Furthermore, a multivalent VEEV vaccine encoding GPC from the distantly related LP and Josiah strains showed protection in inbred CBA/J mice [43]. VEE vectors have also been used for targeting other arenaviruses such as Junin virus (JUNV) and Machupo virus (MACV) [44]. VEEV-based expression of JUNV- and MACV-GPC, respectively, elicited humoral immune responses and provided protection in guinea pigs after immunization with $1 \times 10^{7} \mathrm{pfu}$.

Table 2. Examples of clinical studies on self-replicating RNA viral vector vaccines against infectious diseases.

\begin{tabular}{|c|c|c|c|c|}
\hline Virus/Disease & Antigen & Vector & Findings & Ref. \\
\hline \multicolumn{5}{|l|}{ Alphaviruses } \\
\hline CHIKV/CHIK & C, Env & MV-CHIKV VLPs & Phase I: $100 \%$ seroconversion after two doses & [96] \\
\hline CHIKV/CHIK & C, Env & MV-CHIKV VLPs & Phase II: good safety, strong immunogenicity & [97] \\
\hline \multicolumn{5}{|l|}{ Filoviruses } \\
\hline EBOV/EVD & GP (Zaire strain) & VSV-ZEBOV & Phase III: high vaccine efficacy, protection & {$[99,100]$} \\
\hline EBOV/EVD & GP (Zaire strain) & VSV-ZEBOV & Phase III: high vaccine efficacy & [100] \\
\hline EBOV/EVD & GP (Zaire strain) & VSV-ZEBOV & Ervebo approval by the FDA, EMA & [101] \\
\hline \multicolumn{5}{|l|}{ Flaviviruses } \\
\hline ZIKV/ZVD & $\mathrm{E}$ & MV-ZIKA-E & Phase I: study completed; no results available & [102] \\
\hline ZIKV /ZVD & $\mathrm{E}$ & MV-ZIKA-RSP-E & Phase I: study in progress & [103] \\
\hline \multicolumn{5}{|l|}{ Lentiviruses } \\
\hline HIV / AIDS & HIV Gag & VEEV-Gag & Phase I: trials halted, stability \& documentation & [104] \\
\hline \multicolumn{5}{|l|}{ Coronaviruses } \\
\hline SARS-CoV-2/COV & $\mathrm{S}$ & MV (TMV-083) & Phase I: weak immunogenicity, trial discontinued & {$[75,76]$} \\
\hline SARS-CoV-2/COV & S & VSV (V590) & Phase I: weak immunogenicity, trial discontinued & {$[78,79]$} \\
\hline SARS-CoV-2/COV & S & VSV $\Delta \mathrm{G}-\mathrm{S}$ & Phase I/II: study in progress & {$[81,82]$} \\
\hline SARS-CoV-2/COV & S & LNP-VEEV-S RNA & Phase I/II: study in progress & [85] \\
\hline
\end{tabular}

C, capsid, CHIKV, Chikungunya virus; COV, COVID-19; EBOV, Ebola virus; E \& Env, envelope proteins; EVD, Ebola virus disease; GP; Glycoprotein; S, spike protein; SARS, severe acute respiratory syndrome; VEEV, Venezuelan equine encephalitis virus; VLPs, virus-like particles; VSV, vesicular stomatitis virus; ZIKV, Zika virus; ZVD, Zika virus disease.

Among filoviruses, especially EBOV has been a common target for vaccine development due to its transmissibility and the severity of Ebola virus disease (EVD) during outbreaks in 2014-2016 [105]. In one approach, the EBOV glycoprotein (GP) D637L mutant, which displays superior cleavability and shedding compared to wildtype GP, was expressed from a KUN vector [45]. Two subcutaneous doses of $1 \times 10^{9} \mathrm{KUN}-\mathrm{GP} / \mathrm{D} 637 \mathrm{~L}$ VLPs was sufficient to provide protection in three out of four immunized nonhuman primates. In another study, when macaques vaccinated with $5 \times 10^{7}$ VSV-EBOV GP particles were challenged with the EBOV-Makona [46] and Zaire (ZEBOV) [47] strains, they were resistant to EVD. The VSV-based EBOV-GP vaccine (VSV-ZEBOV) has been subjected to phase III clinical evaluation in 7651 individuals with suspected EVD, of which 4123 were vaccinated immediately and 3528 received a delayed vaccination [99]. No EVD cases were detected in individuals immediately vaccinated while 16 EVD cases were observed among those receiving delayed vaccination, which indicated that the vaccination was successful. Another phase III trial confirmed the efficacy, where no new EVD cases were detected in 
neither the 2119 individuals who received immediate vaccination nor in the 2041 subjected to a 21-day delay in vaccine administration [100]. The VSV-ZEBOV vaccine has been approved by both the FDA and the EMA [101]. In the context of other filoviruses, VEEV-based expression of the Marburg virus (MARV) GP provided protection in macaques against MARV challenges after immunization with $1 \times 10^{7} \mathrm{pfu}$ of VEEV-MARV-GP particles [100]. A VEEV vector expressing the Sudan virus (SUDV) GP was subjected to intramuscular administration of $1 \times 10^{10}$ particles in cynomolgus macaques, which protected the vaccinated animals against SUDV challenges [48]. Moreover, macaques immunized with VEE-SUDV GP particles provided partial protection against EBOV challenges. Macaques co-administrated with VEEV-SUDV-GP and VEEV-EBOV-GP were protected against both SUDV and EBOV challenges.

In the context of flaviviruses, BALB/c mice immunized with a single dose of VEEV particles expressing the ectodomain of the DENV envelope resulted in protective immunity against challenges with DENV [49]. Moreover, immunization of mice with $2 \times 10^{6} \mathrm{pfu}$ of an MV vector expressing the DENV envelope protein domain III (ED3) elicited robust immune responses and resulted in partial protection against DENV [50]. A live-attenuated chimeric YFV-DENV tetravalent vaccine (CYD-TDV) has been engineered and tested in rodent and primate models, showing no toxicity, good safety, and robust immune responses [51,52]. The CYD-TDV vaccine has been tested in endemic populations [53].

In another approach, VEEV replicon RNA was engineered to express the codon optimized Zika virus (ZIKV) membrane-envelope protein (prME) [54]. The delivery of the VEEV-ZIKV-prME replicon RNA was facilitated by formulation of nanocarrier lipids (NLCs). A single intramuscular dose of $10 \mathrm{ng}$ RNA provided complete protection against ZIKV challenge. Moreover, a single immunization of mice with $1 \times 10^{7} \mathrm{pfu}$ of the chimeric VSV vector expressing the ZIKA-prME resulted in robust antibody responses and rendered mice resistant to ZIKV challenges [32]. A live MV-based vaccine expressing the ZIKV E gene (MV-E2) provided protection against the nonlethal ZIKV Asian strain PRVABC59 and the lethal African strain MR766 in mice [55]. Despite 100\% survival complete viral clearance in the brain and reproductive tract did not occur. However, co-administration of an MV vector expressing the ZIKV NS1 gene (MV-NS1 [2]) led to complete clearance of ZIKV from the female reproductive tract and fetal protection was achieved.

Although most clinical trials conducted on ZIKV vaccines are based on inactivated or attenuated viruses and nucleic acids [106], a dose-finding phase I study with MV-ZIKA (MV-E2) was carried out in 48 individuals, however, no results have been published yet [102]. Furthermore, another phase I trial to validate the safety and immunogenicity of MV-ZIKA is in progress in healthy 18-55-year-old volunteers in Austria [103].

Although HBV vaccines have been approved [107] there is still need for new vaccine development due to the discovery of breakthrough infections, for instance. In attempts to target $\mathrm{HBV}$, MV vectors have been used for the expression of the surface antigen (HBsAg) [56]. Immunization with HBV-HBsAg resulted in 50\% protection of rhesus monkeys. In another approach, the SFV RNA replicon expressing the HBV middle surface envelope glycoprotein $(\mathrm{MHB})$ and the core antigen ( $\mathrm{HBcAg}$ ) were packaged into a VSV G envelope [57]. Mice immunized with $1 \times 10^{7} \mathrm{pfu}$ of SFV-G-MHB were protected against HBV challenges, while SFV-HBcAg immunizations did not provide protection. So far clinical trials on HBV vaccines have focused mainly on DNA, live virus, and peptide-based approaches [108]. Only one adenovirus-based phase I trial has been described [109]. No published data is available for clinical applications of self-replicating RNA vector-based HBV vaccines.

The HIV / AIDS epidemic has obviously accelerated the development of vaccines against HIV. Live attenuated MV vectors expressing HIV-1 Gag like particles with a gp160 Env protein envelope elicited robust cellular and humoral immune responses in mice [58]. Much attention has been dedicated to alphavirus-based HIV vaccine development. For example, mice immunized with SFV-HIV-Env particles showed superior antibody titers compared to plasmid DNA and recombinant Env protein [59]. Furthermore, intramuscular 
administration of SFV-HIV-Env replicon RNA induced Env-specific immune responses in four out of five mice [60]. In another approach, immunization of mice with SFV particles expressing the Indian HIV-1C Env-Gag-Pol-RT genes elicited significant T-cell responses with higher antibody titers compared to replicon RNA immunization [61]. SFV DNA replicon delivery of HIV Env and a Gag-Pol-Nef fusion protein generated strong immune responses in immunized BALB/c mice [62]. In attempts to improve stability and delivery of VEE-HIV-1 gp140 RNA replicons, cationic nanoemulsion (CNE) formulations consisting of squalene, 1,2-dioleoyl-3-tri-methylammonium-propane (DOTAP) and sorbitan trioleate were developed [63]. In a comparative study, intramuscular injection of $50 \mu \mathrm{g}$ of VEEV RNA-CNE elicited stronger immune responses in rhesus macaques than what was obtained for VEEV particles or MF59 adjuvanted HIV gp140 protein [110]. In the case of clinical evaluations for self-replicating RNA virus-based HIV vaccines, the safety and immunogenicity of an alphavirus replicon HIV-1 Gag vaccine (AVX101) was subjected to a double-blind, randomized, placebo-controlled trial in healthy adults [104]. The study was conducted in the US and South Africa, but it was halted due to vaccine stability issues. Another phase I trial was initiated, but it was prematurely terminated because of documentation issues encountered by the contract manufacturer. However, the study results indicated that in contrast to preclinical findings, only low levels of immune responses were elicited in humans. Measurement of anti-vector antibodies showed only modest local reactogenicity.

The importance of vaccine development against influenza virus relates to the occurrence of seasonal global outbreaks. In the context of MV, a recombinant MV AIK-C vaccine expressing the hemagglutinin (HA) protein from the influenza A/Sapporo/107/2013 (H1N1pdm) strain elicited strong immune responses in cotton rats and provided protection against challenges with influenza virus [64]. In the case of VSV, the VSV $\Delta G$ vector lacking the VSV G protein was engineered to express the HA protein of the highly pathogenic avian influenza virus (HPAIV) A/Vietnam/1203/04 (VN1203) strain and the neuraminidase (NA protein) of the mouse-adapted H1N1 influenza virus A/Puerto Rico/8/34 (PR8) [65]. A single immunization of mice with VSV $\Delta$ G-H5N1 provided protection against lethal H5N1 infection. In another study, a VSV-based H5N1 influenza virus vector containing the full-length hemagglutinin (HAfl) was administered as a single dose or a prime-boost regimen in mice, generating protection against lethal challenges with various $\mathrm{H} 5$ clade 2 viruses [66]. In the context of alphaviruses, a single dose of $1 \times 10^{7} \mathrm{pfu}$ of VEE-HA resulted in protection against influenza A virus isolate A/HK/156/97 challenges in chickens [67]. In another study, $10 \mu \mathrm{g}$ of SFV-HA replicon RNA provided protection in $90 \%$ of vaccinated BALB/c mice [68]. The superiority of self-replicating replicon RNA was confirmed by demonstrating that only $1.25 \mu \mathrm{g}$ was required to provide protection in mice compared to $80 \mu \mathrm{g}$ needed for synthetic mRNA [69]. In a novel approach, the external domain of the influenza virus M2 protein (M2e) was introduced into the E2 membrane protein in a SIN vector, resulting in SIN particles (E2S1-M2e) with M2e expressed on its surface [70]. Mice intranasally immunized with SIN E2S1-M2e were protected from challenges with a virulent influenza A virus strain. As CSFV targets monocytes and dendritic cells (DCs) the nucleoprotein (NP) and HA genes of influenza virus were inserted into the CSFV replicon RNA (RepRNA) vector [71]. Packaging of a Rep-HA/Rep-NP mix in viral replicon particles (VRPs) was compared with polyethylenimine (PEI)-based RNA complexes and naked RepRNA in pigs. Both VRPs and PEI-RepRNA complexes elicited strong HA and NP specific humoral and cellular immune responses, whereas naked RNA induced only low-level immunogenicity. Overall, CSFV VRPs showed superior immunogenicity in pigs.

The current COVID-19 pandemic has promoted vaccine development to a new level. The breath and intensity of global activities related to vaccines have been unprecedented leading to EUA of both nucleic acid- [111,112] and viral vector-based [2-4] COVID-19 vaccines in approximately a year from the onset of the outbreak. As the authorized viral vector based COVID vaccines are based on adenoviruses they are not discussed here, and the focus of the current review will be on self-replicating RNA viruses. Prior to COVID-19 vaccines, both SARS-CoV and Middle East respiratory syndrome-coronavirus (MERS-CoV) 
have been targeted. For example, mice immunized with a VEEV vector expressing the SARS-CoV Spike (S) protein resulted in protection against SARS-CoV challenges [72]. In the context of MERS-CoV, the VSV G protein was replaced by the MERS-CoV S protein [73]. A single intramuscular or intranasal immunization with VSV $\Delta$ G-MERS-CoV S elicited neutralizing antibodies and $\mathrm{T}$ cell responses in rhesus macaques.

Obviously due to the COVID-19 pandemic, SARS-CoV-2 has received major attention as a vaccine target. MV-based expression of the SARS-CoV-2 $\mathrm{S}$ protein elicited robust Th1biased antibody and $\mathrm{T}$ cell responses in mice [74]. The MV-SARS-CoV-2 S vaccine candidate TMV-083 was subjected to a randomized, placebo-controlled phase I clinical trial, which based on disappointing weak immune responses in vaccinated volunteers was discontinued $[75,76]$. VSV vectors have also been applied for overexpression of the SARS-CoV-2 S protein [77]. Immunization of mice with VSV-SARS-CoV-2 S particles elicited neutralizing antibody responses and protected against SARS-CoV-2 related pathogenesis. In the context of clinical trials, the VSV-SARS-CoV-2 S vaccine candidate V590 was evaluated in a phase I clinical trial in 252 volunteers [78]. The immunization proved safe and showed good tolerability, but the immune responses were weaker than seen in COVID-19 patients, which justified the termination of the trial [79]. In another approach the replication competent VSV $\Delta G$ vector was engineered by replacing the VSV G protein with the SARS-CoV-2 S protein [80]. A single immunization with $5 \times 10^{6}$ pfu of VSV $\Delta$ G-SARS-CoV-2 S elicited potent neutralizing antibodies and protected Syrian golden hamsters against challenges with SARS-CoV-2. In the case of clinical trials, the VSV $\Delta$ G-SARS-CoV-2 $\mathrm{S}$ vaccine candidate is subjected to a phase I/II clinical study, where volunteers will receive a single dose of $5 \times 10^{5}, 5 \times 10^{6}$, or $5 \times 10^{7}$ pfu of VSV $\Delta$ G-SARS-CoV-2 in the first part of the study [81]. As the trial is still in progress the interim experience has caught attention as other vaccines have received EUA and the ethical question has been raised whether individuals in the placebo group should be entitled to other vaccines during the study period [82]. The decision was to balance the individual risk with the common good of participants without compromising the quality of randomized studies. In the context of animal coronaviruses, the chimeric flavivirus BVDV vector was applied for the expression of a spike antigen of the porcine epidemic diarrhea virus (PEDV) [83]. Intramuscular injection of BALB/c mice elicited BVDV- and PEDV-specific antibodies and neutralized both BVDV and PEDV.

Self-amplifying RNA viruses have also been used in COVID-19 vaccine development as liposome nanoparticle (LNP) encapsulated RNA replicons. In this context, VEEV-based RNA replicons were engineered to express the prefusion-stabilized SARS-CoV-2 S RNA [84]. Intramuscular administration of LNP SARS-CoV-2 S RNA in BALB/c mice elicited robust and dose-dependent SARS-CoV-2 specific antibody responses and SARS-CoV-2 neutralization. The antibody titers were superior to those seen in recovered COVID-19 patients. The LNP SARS-CoV-2 S RNA vaccine candidate has been subjected to a randomized, placebo-controlled, dose-finding phase I/II study in healthy volunteers [85]. No results from the study are available yet. In another study, the VEEV-based self-replicating RNA (STARR)-based vaccine (LUNAR-COV19) expressing the full-length SARS-CoV-2 S protein has been evaluated in BALB/c mice [86]. A single immunization elicited strong neutralizing antibody responses and both $2 \mu \mathrm{g}$ and $10 \mu \mathrm{g}$ doses protected humanized ACE2 transgenic mice from mortality and measurable infection after challenges with wildtype SARS-CoV-2. Recently, SIN particles expressing the SARS-CoV-2 S protein were combined with the OX40 immunostimulatory antibody $(\alpha \mathrm{OX} 40)$ for intraperitoneal immunization of C57BL/6J mice [87]. A prime-boost vaccination strategy with 14 days between the two doses elicited long-lasting neutralizing antibodies and robust T-cell responses and sera from vaccinated mice inhibited the function of the SARS-CoV-2 $S$ protein. Furthermore, immunized mice were protected against challenges with SARS-CoV-2.

In addition to viral targets, bacterial and parasite infections have also been studied. For example, SIN vectors have been applied for the expression of the Bacillus anthracis protective antigen (PA) [88]. Immunization of Swiss Webster mice elicited PA-specific IgG and neutralizing antibody responses and provided some protection against a lethal 
bacterial strain. SFV particles expressing the Brucella abortus translation initiation factor 3 (IF3) elicited IF3-specific IgM antibodies and T cell proliferative responses and protected immunized BALB/c mice [89].

In the context of parasites and malaria vaccines, SFV particles expressing the Plasmodium falciparum Pf332 antigen were subjected to immunization studies in BALB/c mice [90]. A single immunization elicited Th1-type immune responses, which were further enhanced by a second immunization. In another approach, the Plasmodium yoelii circumsporozoite (CS) protein class I major histocompatibility complex-restricted-9-mer epitope SYVPSAEQI was expressed from a SIN vector [91]. Subcutaneous immunization of BALB/c mice with SIN-Mal particles induced robust epitope-specific $\mathrm{CD} 8^{+} \mathrm{T}$ cell responses and provided protection against malaria. Recently, the Phlebotomus papatasi SP15-Leishmania major stress inducible protein 1 (PpSP15-LmSTI1) fusion protein was compared for expression in BHK21 cells after transfection of SFV replicon RNA, SFV DNA replicons and a conventional DNA plasmid [92]. The relative expression was significantly higher for the SFV replicon RNA than both SFV and conventional DNA vectors, making it an attractive alternative for vaccine development against leishmaniasis.

\section{Cancer}

Self-replicating RNA viruses have also been applied for cancer immunotherapy and cancer vaccine development [5]. The general approach has been to introduce a tumor antigen into the self-replicating RNA viral vector for immunization studies, which have demonstrated both prophylactic and therapeutic efficacy in preclinical animal models. Other approaches have involved expression of immunostimulatory genes such as cytokines and even reporter genes. Obviously, the application of reporter genes such as GFP and luciferase allows efficient monitoring of expression. The therapeutic effect seen after administration of alphavirus vectors expressing reporter genes relates to the induction of apoptosis, but the efficacy has been inferior compared to treatment with alphavirus vectors expressing cytokines like interleukin-12 (IL-12) [113]. While cancer vaccines aim at providing protection against tumor development, oncolytic viruses possess therapeutic activity, also named virotherapy, for the treatment of existing tumors [114]. Oncolytic viruses are characterized by efficient replication in and killing of tumor cells without causing harm to normal cells, which make them attractive for cancer therapy. There are different types of engineered oncolytic viruses such as herpes simplex virus, adenovirus, vaccinia virus and reovirus. Moreover, naturally oncolytic viruses have been identified for Newcastle disease virus [115]. Among self-replicating RNA viruses, attenuated MV strains [116], engineered VSV vectors [117], and the naturally oncolytic M1 alphavirus [118] exist. Although the focus is on prophylactic and therapeutic cancer vaccines, examples of virotherapy are also included here. So far, a limited number of clinical trials have also been conducted. Examples of preclinical studies and clinical trials are presented below and summarized in Tables 3 and 4.

Table 3. Examples of preclinical studies on self-replicating RNA viral vector vaccines against cancers.

\begin{tabular}{ccccc}
\hline Cancer & Antigen/Therapeutic & Vector & Findings \\
\hline Brain & & & Ref. \\
\hline Glioblastoma & Endostatin & SFV & Complete tumor regression in mice \\
Glioblastoma & IL-18 & DC-SFV + IL-12 & Enhanced Th1-type response, anti-tumor immunity & [120] \\
Glioblastoma & gp100, IL-18 & SIN DNA & Therapeutic effect, prolonged survival in mice & [121] \\
Glioblastoma & CHIKV E3-E2-6K-E1 & VSVDG-CHIKV & Selective infection, elimination of tumor cells & [122] \\
Glioblastoma & GFP, CEA, NIS & GSC-MV & Anti-tumor effect, prolonged survival in mice & [123] \\
Glioblastoma & EGFP & SFV VA & Tumor inhibition, prolonged survival in mice & [124] \\
CT-2A glioma & miRT124 & SFV4 & Replication in tumor cells, prolonged survival & [125] \\
\hline
\end{tabular}


Table 3. Cont.

\begin{tabular}{|c|c|c|c|c|}
\hline Cancer & Antigen/Therapeutic & Vector & Findings & Ref. \\
\hline \multicolumn{5}{|l|}{ Breast } \\
\hline A2L2 & HER2/neu & Ad/SIN DNA & Prolonged survival in mice & [126] \\
\hline A2L2 & HER2/neu & Ad + SIN DNA & Tumor protection in mice with $80 \%$ less DNA & [127] \\
\hline HER2 & HER2 ECD, TMs & VEEV (VRP-HER2) & Preventive, therapeutic tumor growth control in mice & [128] \\
\hline $4 \mathrm{~T} 1$ & IL-12 & $\mathrm{SFV}+$ S. typhimurium & Inhibition of metastasis, long-term survival in mice & [129] \\
\hline TNBC & M1 & M1 + Doxorubicin & Synergistic effect of M1 and Doxorubicin & [118] \\
\hline MCF7 & SLAMblind & MV & Targeting and killing of breast cancer cells & [130] \\
\hline \multicolumn{5}{|l|}{ Cervical } \\
\hline HPV-16 & Capsid & MV & Humoral immune responses in mice & [131] \\
\hline HPV-16 & Capsid & MV + HPV protein & IgG and neutralizing antibody responses & [132] \\
\hline CRPV & $\mathrm{E} 1, \mathrm{E} 2, \mathrm{E} 6, \mathrm{E} 7$ & VSV & Reduced papilloma volumes, elimination of disease & [133] \\
\hline HPV-16 & E7 & VSV & Tumor regression in mice & [134] \\
\hline HPV-16 & E7 & VEEV & Immune response, protection against tumors in mice & [135] \\
\hline HPV-16 & E6/E7 fusion & SFVEnh & Tumor regression, complete eradication & [136] \\
\hline HPV & E6-E7 & SFV DNA + EP & $85 \%$ of immunized mice became tumor-free & [137] \\
\hline \multicolumn{5}{|l|}{ Colon } \\
\hline CT26 & GM-CSF & KUN & Tumor regression, cure in 50\% mice & [138] \\
\hline СТ26 & VEGFR-2 & SFV & Inhibition of tumor growth, metastasis & [139] \\
\hline СТ26 & VEGFR-2 + IL-4 & SFV & Super immunogenicity, prolonged survival & [139] \\
\hline CT26 & LacZ & SFV RNA & Tumor regression, protection against tumor cells & [140] \\
\hline MC28cea & GM-CSF & MV & Tumor regression, prevention of re-engraftment & [141] \\
\hline \multicolumn{5}{|l|}{ Lung } \\
\hline H358cea & EGFP & SFV & Protection against $\mathrm{HBV}$ in $50 \%$ of rhesus monkeys & [142] \\
\hline A549 & EGFP & SFV VA & Superior survival compared to adenovirus delivery & [143] \\
\hline CT26 & $\mathrm{LacZ}$ & SIN & Complete tumor remission, prolonged survival & [144] \\
\hline CL25 & oMV & MV Hu-191 & Suppressed tumor growth, prolonged survival & [145] \\
\hline LLC & oMV & MV Schwarz & Suppression of uncontrollable tumor growth & [146] \\
\hline Adenocarcinoma & CEA & MV & Tumor regression in mice & [147] \\
\hline H2009, A549 & $\mathrm{IFN} \beta$ & VSV & Tumor regression in mice & [148] \\
\hline LM2 & $\operatorname{IFN} \beta$ & VSV & Prolonged survival, cure in $30 \%$ of mice & [148] \\
\hline \multicolumn{5}{|l|}{ Melanoma } \\
\hline B16-OVA & GM-CSF & KUN & Tumor regression, cure of more than $50 \%$ of mice & [138] \\
\hline $\begin{array}{l}\text { B16-OVA, } \\
\text { B16F0 }\end{array}$ & SIIINFEKL epitope & YFV & Immune response, protection in mice & [149] \\
\hline B16 & TRP-2 & VEEV & Immune response, prolonged survival in mice & [150] \\
\hline B16 & TRP-2 & VEEV + GITR mAb & Complete tumor regression in $90 \%$ of mice & [151] \\
\hline B16 & TRP-2 & $\mathrm{VEEV}+\mathrm{CTLA}-4 \mathrm{mAb}$ & Complete tumor regression in $50 \%$ of mice & [151] \\
\hline B16 & $\begin{array}{l}\text { VEGFR-2/IL-12 + } \\
\text { survivin/ } \beta \text {-hCG }\end{array}$ & SFV DNA & $\begin{array}{l}\text { Superior tumor growth inhibition, prolonged } \\
\text { survival after combination therapy }\end{array}$ & [152] \\
\hline mel Z & oMV & MV L-16 & Tumor cell killing, inhibition of tumor growth & [153] \\
\hline B16-OVA & LCMV GP & VSV & Efficacy in subcutaneous tumor models & [154] \\
\hline \multicolumn{5}{|l|}{ Ovarian } \\
\hline A2780 & LCMV GP & VSV + ruxolitinib & Tumor regression in mice & [155] \\
\hline SKOV3ip.1 & $\alpha \mathrm{FR} \mathrm{scFV}$ & MV & Tumor volume reduction, prolonged survival & [156] \\
\hline SKOV3ip.1 & CEA, NIS & MV & Dual therapy superior in mice & [157] \\
\hline ES2 & IL-12 & SIN + irinotecan & Long-term survival in mice & [158] \\
\hline MOSEC & OVA & $\mathrm{SFV}+\mathrm{VV}$ & Immune response, enhanced anti-tumor activity & [159] \\
\hline \multicolumn{5}{|l|}{ Pancreatic } \\
\hline PDAC & GFP & VSV & Superior oncolytic activity compared to Sendai, RSV & [160] \\
\hline PDAC & GFP & VSV- $\Delta \mathrm{M} 51$ & Anti-tumor activity enhanced by gemcitabine & [161] \\
\hline KLM1 & SLAMBlind & MV & Suppression of tumor growth in mice & [162] \\
\hline Capan-2 & SLAMBlind & MV & Suppression of tumor growth in mice & [162] \\
\hline
\end{tabular}


Table 3. Cont.

\begin{tabular}{|c|c|c|c|c|}
\hline Cancer & Antigen/Therapeutic & Vector & Findings & Ref. \\
\hline \multicolumn{5}{|l|}{ Prostate } \\
\hline PC-3 & CEA & MV & Delay in tumor growth, prolonged survival in mice & {$[163]$} \\
\hline PC-3 & $\mathrm{oMv}, \mathrm{oMuV}$ & $\mathrm{MV}+\mathrm{MuV}$ & Immune responses, protection in mice & {$[164]$} \\
\hline DU145, PC-3 & GFP & VSV- $\Delta \mathrm{M} 51$ & Apoptosis in tumor cells, prolonged survival & {$[165]$} \\
\hline $\begin{array}{l}\text { DU-145, } \\
22 R v 1\end{array}$ & LCMV GP & VSV & Long-term remission in mice & {$[166]$} \\
\hline TRAMP-C & PSMA & VEEV & PSMA-specific immune response in mice & {$[167]$} \\
\hline TRAMP & STEAP & VEEV & $\begin{array}{c}\text { STEAP-specific immune response, prolonged } \\
\text { survival }\end{array}$ & {$[168]$} \\
\hline TRAMP & PSCA & VEEV & Long-term survival for 12 months in $90 \%$ of mice & {$[169]$} \\
\hline
\end{tabular}

Ad, adenovirus; CEA, carcinoembryonic antigen; CRPV, cottontail rabbit papilloma virus; CSC, glioma stem cell; CTLA-4, CTL antigen-4; DC, dendritic cell; GFP, green fluorescent protein; GITR, glucocorticoid-induced tumor necrosis factor receptor; GM-CSF, granulocyte macrophage-colony stimulating factor; IL. interleukin; KUN, Kunjin virus; LCMV, lymphocytic choriomeningitis virus; Lewis lung carcinoma; MOSEC, murine ovarian surface epithelial carcinoma; MV, measles virus; NIS, sodium iodine symporter; PDAC, pancreatic ductal adenocarcinoma; RROC, refractory recurrent ovary cancer; RSV, respiratory syncytial virus; SFV, Semliki Forest virus; TNBC, triplenegative breast cancer; SIN, Sindbis virus; STEAP, six-transmembrane epithelial antigen of the protein; TRAMP, transgenic adenocarcinoma mouse prostate; VEEV, Venezuelan equine encephalitis virus; VEGFR-2, vascular endothelial growth factor receptor-2; VSV, vesicular stomatitis virus; YFV, yellow fever virus.

Table 4. Examples of clinical studies on self-replicating RNA viral vector vaccines against cancers.

\begin{tabular}{|c|c|c|c|c|}
\hline Cancer & Antigen/Therapeutic & Vector & Findings & Ref. \\
\hline \multicolumn{5}{|l|}{ Breast } \\
\hline HER2 & HER2 ECD TMs & VEEV (VRP-HER2) & Phase I: immune response, PR and SD & [128] \\
\hline HER2 & HER2 ECD TMs & VEEV (VRP-HER2) & Phase II: study in progress & [170] \\
\hline \multicolumn{5}{|l|}{ Cervical } \\
\hline HPV-16 & E6/E7 fusion & SFVEnh (Vvax001) & Phase I: safe, immune responses in all patients & [171] \\
\hline \multicolumn{5}{|l|}{ Colon } \\
\hline Stage III-IV & CEA & VEEV & Phase I: immune responses, prolonged survival & [172] \\
\hline \multicolumn{5}{|l|}{ Ovarian } \\
\hline RROC & CEA & MV & Phase I: well-tolerated, dose-dependent activity & [173] \\
\hline \multicolumn{5}{|l|}{ Pancreatic } \\
\hline Metastatic & CEA & VEEV & Phase I: immunogenicity, prolonged overall survival & [174] \\
\hline
\end{tabular}

CEA, carcinoembryonic antigen; MV, measles virus; RROC, refractory recurrent ovary cancer; VEEV, Venezuelan equine encephalitis virus.

Brain tumors have been the target of several studies due to the severity of disease and very few alternative options of successful treatment. For instance, SFV particles expressing endostatin were compared to a retrovirus vector expressing endostatin, and SFV-LacZ in a B16 brain tumor mouse model [119]. Intratumoral administration of SFVEndostatin showed significant tumor growth inhibition and reduction of intratumoral vascularization, which was superior to both retrovirus and SFV-LacZ treatments. In addition, intravenous SFV-Endostatin administration generated 3-fold increase in serum levels of endostatin. In another approach, intratumoral injection of DCs transduced with SFV particles expressing interleukin-18 (IL-18) in combination with recombinant IL-12 protein therapy, elicited Th1-type immune responses and provided anti-tumor immunity in a B16 brain tumor mouse model [120]. Furthermore, a SIN DNA replicon encoding the human gp100 and mouse IL-18 was evaluated in B16-gp100 implanted brain tumor models in mice [121]. Immunization with SIN-gp100-IL-18 DNA resulted in therapeutic effects, enhanced protection of malignant brain tumors, and significantly prolonged survival rates. A chimeric VSV vector, where the VSV G protein was replaced by the CHIKV E3-E2-6K-E1 polyprotein (VSV $\Delta \mathrm{G}-\mathrm{CHIKV}$ ), showed selective infection and elimination 
of brain tumor cells [122]. Moreover, tumor-bearing mice showed extended survival for more than 100 days. VSV $\Delta$ G-CHIKV also showed targeting in intracranial melanoma xenografts derived from patients with only minor detectable infection of normal cells. Moreover, oncolytic MV vectors expressing GFP, carcinoembryonic antigen (CEA) and sodium iodide symporter (NIS) have been shown to replicate and providing cytotoxic effects in glioma stem cells (GSCs) [123]. When GSCs transduced with MV-GFP were implanted into the right caudate nucleus of nude mice a significant prolongation of survival was obtained. Application of oncolytic replication competent SFV VA-EGFP particles was evaluated in BALB/c mice in a subcutaneous orthotopic tumor model stably expressing firefly luciferase [124]. A single intravenous administration of SFV VA-EGFP completely inhibited intracranial firefly bioluminescence and provided long-term survival in 16 out of 17 mice. The treatment was well tolerated causing no damage to heart, liver, spleen, or brain.

Applications of alphavirus vectors for cancer immunotherapy and gene therapy of brain tumors have raised some concerns due to their neurotropic nature [175]. In one approach, distribution of recombinant SFV particles (recSFV) and RNA replicons (recRNA) expressing firefly luciferase was compared in tumor-free and 4T1 mammary tumor-bearing mice [176]. Intravenous administration of recRNA resulted in primary brain targeting in both tumor-free and tumor-bearing mice. However, local intratumoral injection led to high levels of luciferase expression in tumors. Interestingly, predominant tumor targeting of recSFV was observed after low intravenous or intraperitoneal viral doses, whereas higher doses led to a broader luciferase distribution. In another approach, neuron-specific microRNA miRT124 sequences were introduced into the replication-competent SFV4 vector, which modified its tropism [125]. A single intraperitoneal administration of SFV4-miRT124 to C57BL/ 6 mice with implanted CT-2A orthotopic gliomas demonstrated significant tumor growth inhibition and provided prolonged survival.

Related to breast cancer, immunization of BALB/c mice with adenovirus particles and SIN DNA replicons expressing the HER2/neu gene inhibited A2L2 tumor growth [126]. However, if the tumor challenges took place prior to immunization, no inhibition was observed. A strategy of prime immunization with SIN DNA followed by a boost with adenovirus particles significantly prolonged the survival of mice. In another study, intradermal administration of BALB/c mice with SIN-HER2/neu DNA replicons generated robust antibody responses and required $80 \%$ less replicon DNA than conventional plasmid DNA to achieve tumor protection [127]. In another study, a novel VEEV vector expressing the extracellular domain (ECD) and transmembrane (TM) domains of HER2 (VRP-HER2) showed robust immunogenicity, both preventive and therapeutic efficacy. and control of tumor growth in a HER2 transgenic mouse model [128]. Moreover, VRP-HER2 showed good tolerance in a phase I trial in stage IV HER2 overexpressing breast cancer patients and generated partial response (PR) in one patient and continued stable disease (SD) in two other patients [170]. Additionally, a phase II trial on VRP-HER2 and pembrolizumab in 39 HER2-positive breast cancer patients is in progress [170]. In another study, $2 \times 10^{8}$ SFV-IL12 particles and $2 \times 10^{7}$ units of an aroC ${ }^{-}$Salmonella typhimurium strain (LVR01) were administered to mice with $4 \mathrm{~T} 1$ tumor nodules, which provided complete inhibition of lethal lung metastases and long-term survival in 90\% of immunized mice [129]. Compared to administration of either SFV-IL12 or LVR01 alone, the synergistic effect of combination therapy presents a promising alternative for prevention and eradication of metastases in advanced breast cancer. In the case of triple-negative breast cancer (TNBC), the most aggressive breast cancer molecular subtype, Doxorubicin was demonstrated to increase the oncolytic effect of the oncolytic M1 alphavirus by 100-fold, specifically in TNBC cells in vitro and significantly inhibited tumor growth in vivo [118]. In the context of MV, reverse genetics was applied to engineer a recombinant MV named rMV-SLAMblind, which is selectively unable to use the signalling lymphocyte activation molecule (SLAM) [130]. Unlike the MV-Edmonston vaccine strain, rMV-SLAMblind used the polio virus receptor-related 4 (PVRL4) as a receptor to infect breast cancer cells showing superior oncolytic activity. 
In vivo studies of rMV-SLAMblind in monkeys showed no clinical symptoms, suggesting that the vector could be a promising oncolytic candidate for breast cancer therapy.

Although the recombinant protein-based human papilloma virus (HPV) vaccine Gardasil was approved by the FDA in 2006 against cervical cancer [177], there is a continuous development in this area. Recombinant MV expressing the HPV-16 L1 capsid protein was subjected to immunization studies in transgenic mice, which resulted in strong humoral immune responses [131]. In another study, the MV-HPV16 L1 capsid vaccine was compared to recombinant HPV16L1 and 18L1 protein vaccines produced in Pichia pastoris in immunized non-human primates [132]. Both MV- and P. pastoris-based vaccines induced immune responses. Prime-boosting combination immunization elicited HPV-specific total IgG and neutralizing antibodies, which was not affected by pre-existing antibodies against MV. Moreover, recombinant VSV vectors have been utilized for the expression of the cottontail rabbit papillomavirus (CRPV) E1, E2, E6, and E7 proteins and immunization of rabbits [133]. VSV-E1, E2, E6, and E7 immunizations significantly reduced papilloma volumes, the VSV-E7 being the most efficient reducing the papilloma volumes by $96.9 \%$, which ultimately eradicated the disease. In another approach, mice bearing TC-1 syngeneic tumors were immunized with VSV-HPV E7 [134]. A single intramuscular injection of C57BL/ 6 mice with $5 \times 10^{6}$ pfu of VSV-HPV E7 elicited HPV16 E7 specific T cells and displayed anti-tumor activity resulting in a 10-fold reduction in tumor volume and regression of pre-existing tumors.

Among alphaviruses, VEEV vectors have been utilized for the expression of the HPV16 E7 protein [135]. Immunization of C57BL/ 6 mice elicited CD8 ${ }^{+} \mathrm{T}$ cell responses and protected mice from tumor challenges. In another study, an SFV vector containing the translation enhancer signal from the SFV capsid gene was engineered to express the HPV E6-E7 fusion [136]. Tumor regression and complete eradication of established tumors were observed in immunized C57BL/6 mice. The SFVenh-HPV E6/E7 vaccine candidate Vvax001 has been subjected to a phase I clinical trial in 12 individuals with a history of cervical intraepithelial neoplasia [171]. Patients received three immunizations of $5 \times 10^{5}$, $5 \times 10^{6}, 5 \times 10^{7}$, or $2.5 \times 10^{8}$ infectious SFVenh-HPV E6/E7 particles at a three-week interval. The vaccination showed high safety and tolerability in patients with HPV-induced cancers. HPV-specific immune responses were detected in all 12 patients. SFV DNA replicons have also been employed for HPV vaccine development [137]. Intradermal immunization of mice with SFV-HPV E6-E7 DNA replicons accompanied by electroporation eradicated $85 \%$ of tumors [135]. The efficacy of DNA replicon immunization compared to conventional plasmid DNA demonstrated that a 200-fold lower dose of only $0.05 \mu \mathrm{g}$ of SFVDNA was sufficient for therapeutic efficacy.

Colon cancers have also been targeted by self-replicating RNA viral vectors. For instance, a noncytopathic KUN vector was engineered to express the granulocyte macrophagecolony stimulating factor (GM-CSF) [138]. Intratumoral immunization of BALB/c mice implanted with $\mathrm{CT} 26$ colon xenografts induced $\mathrm{CD} 8^{+} \mathrm{T}$ cell responses, resulted in tumor regression, and in cure of $50 \%$ of vaccinated mice. SFV particles expressing the vascular endothelial growth factor receptor-2 (VEGFR-2) inhibited tumor growth, reduced tumor angiogenesis, and prevented metastatic spread in immunized BALB/c mice [139]. Additionally, combination therapy of SFV-VEGFR2 and SFV-IL-4 elicited stronger VEGFR-2 antibody responses and provided prolonged survival of vaccinated mice. Immunization with RNA replicons has also been successful, the classic example being the immunization of mice with SFV-LacZ RNA, which elicited antigen-specific CD8 ${ }^{+} \mathrm{T}$ cell responses [140]. A single immunization with $0.1 \mu \mathrm{g}$ SFV-LacZ RNA provided protection against tumor challenges and therapeutic immunization prolonged survival of mice with pre-existing tumors. In a phase I clinical trial, patients with stage IV colorectal cancer received VEEV particles expressing the CEA every three weeks for four immunizations [172]. Later the study was expanded to include stage III patients. Antigen-specific effector T cells were elicited, and long-term survivors were identified suggesting prolonged overall survival. In the case of oncolytic MV vectors the expression of GM-CSF resulted in therapeutic 
efficacy and adaptive immune responses in a colon adenocarcinoma MC38cea model [141]. Intratumoral administration of MV-GM-CSF delayed tumor progression and prolonged survival time. Complete tumor remission was observed in one third of immunized mice and tumor re-engraftment was rejected.

Another area of opportunity is lung cancer. Human H358a non-small cell lung cancer (NSCLC) cells transduced by SFV-EGFP particles were efficiently killed and the growth of H358a spheroids was inhibited [142]. Moreover, nu/nu mice with H358a xenografts were injected with SFV-EGFP particles, which resulted in complete tumor regression in three out of seven mice. In comparison to a conditionally replicating adenovirus vector (Ad5-Delta24TK-GFP), the replication-competent SFV (VA7)-EGFP particles were locally administered to nude mice with A549 lung adenocarcinoma xenografts [143]. Mice immunized with SFV-EGFP showed superior survival compared to adenovirus-based vaccination. Systemic administration, however, did not elicit significant immune responses with either vector. In another approach, SIN-LacZ particles were intravenously administered to mice with implanted CT26.CL25 colon tumors [144]. SIN-LacZ particles induced complete tumor remission and provided long-term survival. MV vectors have also been subjected to lung cancer treatment. In this context, the oncolytic MV Hu-191 strain effectively suppressed tumor growth and significantly prolonged the survival of C57BL/ 6 mice implanted with Lewis lung carcinoma (LLC) cells [145]. It was demonstrated in another study that the live-attenuated oncolytic MV Schwarz strain prevented uncontrollable growth of established lung and colorectal adenocarcinomas in nude mice with xenografts [146]. Similarly, the expression of CEA from the MV Edmonston strain resulted in potent killing of lung cancer cell lines and tumor regression in mice [147]. Additionally, a VSV vector expressing interferon- $\beta$ (VSV-IFN $\beta$ ) reduced tumor growth in intratumorally immunized mice with H2009 and A549 lung tumors [148]. Superior efficacy was achieved by intratumoral administration of VSV-IFN $\beta$ leading to tumor regression, prolonged survival, and cure in $30 \%$ of immunized syngeneic LM2 lung tumors [148].

Melanoma is an indication that has been frequently visited for vaccine development applying viral vectors [178]. For example, immunization of C57BL/ 6 mice carrying B16-OVA melanoma tumors with KUN-GM-CSF particles resulted in substantial tumor regression and cure of more than $50 \%$ of treated animals [138]. Moreover, expression of the chicken ovalbumin (OVA) cytotoxic T cell lymphocyte (CTL) epitope SIINFEKL from an YFV vector induced SIINFEKL-specific CD8 ${ }^{+}$lymphocytes and provided protection against challenges with B16-OVA or B16F0 melanoma cells in immunized C57BL/6 mice [149]. Alphaviruses have also been used for melanoma therapy. For instance, humoral immune responses, anti-tumor activity, and prolonged survival were obtained in a B16 mouse melanoma model after immunization with VEEV particles expressing the tyrosine-related protein-2 (TRP-2) [150]. In another approach, VEEV-TRP-2 particles were combined with antagonist anti-CTL antigen-4 (CTLA-4) or agonist anti-glucocorticoid-induced tumor necrosis factor receptor (GITR) monoclonal antibodies (mAbs) [151]. Immunization with VEEV-TRP-2 and anti-GITR mAbs induced complete tumor regression in $90 \%$ of mice, whereas VEEV-TRP-2 and anti-CTLA-4 treatment resulted in tumor shrinkage in 50\% of animals. In the context of DNA-based delivery, SFV DNA replicons expressing VEGFR-2 and IL-12 from one plasmid vector and survivin and $\beta$-hCG antigens from another plasmid were co-administered to mice with implanted B16 melanoma tumors [152]. The combination immunization provided superior tumor growth inhibition and prolonged survival compared to administration of either SFV DNA replicon alone. In the case of MV vectors, the oncolytic potential of the MV Leningrad-16 (L-16) strain was demonstrated to provide efficient killing of tumor cells and inhibition of tumor growth in the mel $\mathrm{Z}$ mouse melanoma model [153]. Related to VSV, a pseudotyped vector, where the VSV-G protein was replaced by the non-neurotropic lymphocytic choriomeningitis virus (LCMV) glycoprotein (GP), showed efficacy in subcutaneous A375 xenograft and B16-OVA syngeneic mouse tumor models, and also reduced the size of lung metastasis after systemic treatment [154]. 
In the context of ovarian cancer, the pseudotyped VSV-LCMV-GP vector showed oncolytic activity against A2780, HOC7, SKOV6 and other ovarian cancer cell lines and in vivo in the A2780 ovarian mouse tumor model [155]. Tumor regression was further enhanced by combination treatment with the JAK1/2 inhibitor ruxolitinib. MV vectors have also been evaluated for ovarian cancer therapy. Tumor-specific targeting has been achieved by engineering of the MV- $\alpha$ FR vector with a single-chain antibody (scFV) sequence for the alpha-folate receptor $(\alpha \mathrm{FR})$ [156]. Intratumoral injection of MV- $\alpha \mathrm{FR}$ into mice with ovarian SKOV3ip.1 xenografts demonstrated reduced tumor volumes and prolonged overall survival. Moreover, MV-CEA and MV-NIS have been applied alone or in combination for immunization of mice implanted with SKOV3ip.1 xenografts [157]. The dual therapy was superior to either MV-CEA or MV-NIS treatment alone. The MV-CEA vector has been evaluated in a phase I clinical trial in patients with taxol and platinum-refractory recurrent ovarian cancer (RROC) [173]. The study demonstrated that intraperitoneal administration of MV-CEA was well tolerated and provided dose-dependent biological activity in heavily pre-treated patients, of which SD was achieved in 14 out of 21 patients. Alphavirus vectors have also been evaluated for ovarian cancer therapy. Combination therapy of SIN-IL-12 particles and the CPT-11 topoisomerase inhibitor irinotecan provided long-term survival in SCID mice with grafted highly aggressive ES2 human ovarian tumors [158]. In another study, C57BL/6 mice with murine ovarian surface epithelial carcinoma (MOSEC) received a prime immunization of SFV-OVA followed by boost vaccination with vaccinia virus expressing OVA (VV-OVA), which elicited OVA-specific CD8 ${ }^{+} \mathrm{T}$ cell immune responses and enhanced anti-tumor activity [159].

Due to the poor prognosis of pancreatic cancer patients plenty of efforts have been dedicated to the development of vaccines. The oncolytic potential of VSV vectors has been verified in highly aggressive pancreatic ductal adenocarcinoma (PDAC) [160]. In comparison to Sendai virus and respiratory syncytial virus (RSV), VSV showed superior oncolytic activity although PDAC cells were shown to be highly heterogenous to VSV susceptibility reducing the therapeutic efficacy. In another study, wildtype VSV, VSV-GFP and the oncolytic VSV- $\triangle$ M51-GFP were tested in five PDAC cell lines with (+MUC1) or without (MUC1 null) MUC1 expression [161], showing oncolytic activity independent of MUC1 expression. The VSV- $\triangle$ M51-GFP vector generated significant reduction in tumor growth in mice with implanted PDAC xenografts. The anti-tumor activity was improved when gemcitabine was co-administered with VSV. Related to MV vectors, SCID mice with KLM1 and Capan-2 pancreatic tumor xenografts were immunized with MV-SLAMBlind, which resulted in significant suppression of tumor growth [162]. In the case of alphaviruses, a phase I clinical study in pancreatic cancer patients was conducted with VEEV-CEA particles efficiently infecting DCs [174]. Repeated intramuscular injection of VEEV-CEA induced clinically relevant $\mathrm{T}$ cell and antibody responses, which mediated cellular cytotoxicity against tumor cells and prolonged overall survival in patients.

In the context of prostate cancer, a significant delay in tumor growth and prolonged survival was seen in a prostate PC-3 mouse model after intratumoral immunization with MV-CEA [163]. In another application, co-administration of oncolytic MV and mumps virus $(\mathrm{MuV})$ vectors generated superior anti-tumor activity and prolonged survival in the PC-3 prostate cancer model compared to individual administration of MV or MuV [164]. In the context of VSV vectors, the VSV- $\triangle$ M51-GFP showed efficient replication in human DU145, and PC-3 cell lines, which induced apoptosis and killing of tumor cells [165]. In vivo, malignant cells were eradicated while normal tissue was relatively unaffected in nude mice immunized with VSV- $\triangle$ M51-GFP. The survival of immunized mice was also significantly prolonged. In another study, the oncolytic VSV-LCMV-GP efficiently infected 6 different prostate cancer cell lines [166]. Intratumoral and intravenous immunization generated long-term remission of subcutaneous tumors and bone metastases in the DU145 and 22Rv1 prostate tumor mouse models. In the case of alphaviruses, a VEEV vector expressing the prostate-specific membrane antigen (PSMA) elicited strong PSMA-specific immune responses in immunized BALB/c and C57BL/6 mice [167]. Immunization studies with 
VEEV expressing the six-transmembrane epithelial antigen of the protein (STEAP) has been evaluated in prophylactic and therapeutic mouse models [168]. The study demonstrated $\mathrm{CD}^{+} \mathrm{T}$ cell responses against a newly defined mouse STEAP epitope, which prolonged the overall survival of mice. Moreover, TRAMP mice immunized with VEEV particles expressing the prostate stem cell antigen (PSCA) provided long-term survival in $90 \%$ of mice at 12 months post-vaccination [169]. In the context of clinical applications, a phase I study was conducted in patients with castration resistant metastatic prostate cancer (CRPC) by immunization with either $0.9 \times 10^{7}$ or $3.6 \times 10^{7}$ IU of VEEV-PSMA particles [179]. Although the vaccination was well tolerated the PSMA-specific immune response was weak. To address this issue, thorough dose optimization and vector engineering should be considered.

\section{Conclusions}

In summary, numerous examples of applications of self-replicating RNA viral vectors have been presented for targeting both infectious diseases (Tables 1 and 2) and various cancers (Tables 3 and 4). In many cases, target-specific humoral and cellular immune responses have been obtained. In the context of cancer therapy and cancer vaccinations, inhibition of tumor growth, tumor regression and even tumor eradication have been observed. Moreover, immunized animals including mice, guinea pigs and non-human primates were protected against challenges with lethal doses of infectious agents and tumor cells. One attractive characteristic of self-amplifying RNA viruses, especially alphaviruses, is the flexibility of applying them as recombinant viral particles, RNA replicons or layered DNA/RNA vectors (Figure 1). The main feature of RNA replication/amplification has allowed similar immune responses and challenge protection to be achieved for selfreplicating RNA viruses with significantly lower doses compared to conventional viral particles, synthetic RNA, or plasmid DNA. Alternatively, higher doses could potentially induce stronger immune responses. Additionally, the prolonged release of antigens expressed from self-replicating RNA contributes to B cell stimulation and immune stimulation is also enhanced by generation of double-stranded RNA intermediates in transfected cells [69]. Moreover, the rapid RNA degradation renders the heterologous gene expression transient, which is an advantage for vaccine development and cancer therapy, where high-level shortterm expression is preferable. On the other hand, although not the topic of this review, self-replicating RNA virus vectors are not suitable for the treatment of chronic diseases, where long-term gene expression is required. Self-replicating RNA viruses do not possess reverse transcriptase activity and therefore do not integrate into the host genome. However, application of self-replicating RNA viral vectors also presents some disadvantages. In the case of replicon RNA, the ssRNA structure is sensitive to degradation, which demands careful handling and has required RNA encapsulation in LNPs for improved stability and delivery $[84,85]$. RNA-based vaccines have also stricter demands on storage and transportation temperatures. In the case of recombinant self-replicating RNA virus particles, safety concerns have been raised, requiring engineering of helper vectors for conditionally infectious particles [180] and split helper systems [181]. The use of replication-proficient and oncolytic viruses for cancer therapy also needs special attention to ensure that no damage is caused to normal tissue. For instance, alphavirus vectors showing strong neurotropism, engineering of neuron-specific miRT124 sequences restricted replication to tumor cells only, allowing efficient treatment of CT-2A gliomas in mice [125].

Self-amplifying RNA viruses have been applied for some clinical trials. So far, the numbers are significantly lower than what have been seen for adenoviruses, AAV, retroviruses and lentiviruses. However, the positive results obtained so far has encouraged further engineering of improved vectors and delivery systems and optimization of dosing and prime-boost strategies. Reflecting on the success and failure of vaccine development based on self-replicating RNA viral vectors, it is difficult to point out any vector system showing superiority over other systems. Clearly, the choice of target plays a role, especially for vaccines targeting infectious diseases. It might also be good to underline the differ- 
ences between cancer vaccines and vaccines against infectious pathogens. In the case of cancer vaccines, the approach is to provide both prophylactic and therapeutic efficacy and it therefore includes in a broader meaning cancer immunotherapy. For that reason, the repertoire of expressible genes of interest is much larger and in addition to tumor antigens, anti-tumor genes, cytotoxic genes and immunostimulatory genes can be overexpressed to provide preventive or therapeutic effects. Another issue relates to the differences in cancer development and infectious diseases. While viral and bacterial outbreaks can quickly develop into epidemics and even pandemics as familiarly experienced with COVID-19, although many cancers have a high mortality rate, there is no risk of causing epidemics. For this reason, the urgency for cancer vaccines seems to be less prominent compared to infectious diseases, particularly when they have reached pandemic levels.

Related to the efficacy of vaccine development, various self-replicating RNA viral vectors have elicited high neutralizing antibody titers in immunized rodents and nonhuman primates. Moreover, protection has been achieved in rodents and primates against challenges with lethal doses of infectious pathogens. Similarly, immunization of rodents with cancer vaccine candidates has elicited strong immune responses and in certain cases inhibition of tumor growth and/or tumor regression have been observed. Moreover, immunized animals were protected against challenges with tumor cells. Administration of oncolytic viruses has also resulted in tumor regression and in some favorable situations total tumor eradication and cure of treated mice. Typically, transfer from animal studies, particularly studies in mice, has often struggled to generate the same efficacy in clinical trials. This phenomenon has been attributed to different delivery demands in larger animals and humans and suboptimal dosing. For this reason, we should not be discouraged by these setbacks, but continue the engineering of more efficacious delivery vectors and continue dose optimization studies. It might also be advantageous to consider canine tumor models for the following reasons. First, the bigger size of dogs compared to rodents might provide a more similar situation to establish delivery in humans. Second, naturally occurring tumors in canine models resemble more closely human cancers than induced tumors in rodent models. Third, prophylactic and therapeutic evaluation in dogs might lead to veterinary applications in support of human use although it should not be seen as a shortcut to applications in humans. In the context of MV-based vaccines, potential pre-existing immunity against $\mathrm{MV}$, which cannot be assessed in studies in rodents, can compromise the efficacy of vaccines in humans.

The approval by the FDA and the EMA of Ervebo, the VSV-based vaccine against EVD, has given a glimpse of hope for this strategy and further strengthens the position of selfreplicating RNA viral vectors as attractive vehicles for vaccine development. One might ask why it took so long to obtain the approval for the first vaccine based on self-replicating RNA viral vectors? There is obviously no simple answer, and although breakthrough in vector and technology development since the 1980s has been remarkable, especially the combination of omics initiatives including bioinformatics, genomics, proteomics, immunomics, and vaccinomics, all pieces had to come together to guarantee the highest possible safety level of therapeutics and vaccines.

Although efficient vaccines based on adenovirus vectors against COVID-19 have received EUA, issues related to vaccine-induced immune thrombotic thrombocytopenia (VITT) and the circulation of novel more transmissible SARS-CoV-2 variants demonstrate the need for re-engineering of novel vaccines to which self-replicating RNA viral vectors may provide a substantial contribution.

Funding: The author has received no external funding for this review.

Institutional Review Board Statement: No approval needed as no studies involving humans are conducted.

Informed Consent Statement: No studies including humans were conducted, only results have from published studies have been reviewed. 
Data Availability Statement: This is a review, so no experimental data are available.

Conflicts of Interest: The author declares no conflict of interest.

\section{References}

1. Lundstrom, K. Virus vectors for COVID-19 vaccine development. Viruses 2021, 13, 317. [CrossRef]

2. Regulatory Approval of COVID-19 Vaccine AstraZeneca-GOV.UK. Available online: www.gov.uk (accessed on 1 July 2021).

3. Ad26.COV2-S FDA Approval Status. Available online: drugs.com/history/ad26-cov2-s.html (accessed on 10 June 2021).

4. Callaway, E. Russia's fast-track coronavirus vaccine draws outrage over safety. Nature 2020, 584, 334-335. [CrossRef]

5. Lundstrom, K. Application of viral vectors for vaccine development with a special emphasis on COVID-19. Viruses 2020, 12, 1324. [CrossRef]

6. Strauss, J.H.; Strauss, E.G. The alphaviruses: Gene expression, replication and evolution. Microbiol. Rev. 1994, 58, 491-562. [CrossRef]

7. Frolov, I.; Hoffman, T.A.; Pragal, B.M.; Dryga, S.A.; Huang, H.; Schlesinger, S.; Rice, C.M. Alphavirus-based expression vectors: Strategies and applications. Proc. Natl. Acad. Sci. USA 1996, 93, 11371-11377. [CrossRef]

8. Harvey, T.J.; Anraku, I.; Linedale, R.; Harrich, D.; MacKenzie, J.; Suhrbier, A.; Khromykh, A.A. Kunjin virus replicon vectors for human immunedefieciency virus vaccine development. J. Virol. 2003, 77, 7796-7803. [CrossRef]

9. Mühlebach, M.D.; Hutzler, S. Development of Recombinant Measles Virus-Based Vaccines. Methods Mol. Biol. 2017, 1581, 151-168. [PubMed]

10. Lyles, D.S.; Rupprecht, C.E. Rhabdoviridiae. In Fields' Virology, 5th ed.; Knipe, D.M., Howley, P.M., Eds.; Wolters Kluwer Health/Lippincott Williams \& Wilkins: Philadelphia, PA, USA, 2007; pp. 1364-1408.

11. Liljestrom, P.; Garoff, H. A new generation of animal cell expression vectors based on the Semliki Forest virus replicon. Biotechnology 1991, 9, 1356-1361. [CrossRef]

12. Xiong, C.; Levis, R.; Shen, P.; Schlesinger, S.; Rice, C.M.; Huang, H.V. Sindbis virus: An efficient, broad host range vector for gene expression in animal cells. Science 1989, 243, 1188-1191. [CrossRef] [PubMed]

13. Davis, N.L.; Willis, L.V.; Smith, J.F.; Johnston, R.F. In vitro synthesis of infectious Venezuelan equine encephalitis virus RNA from a cDNA clone: Analysis of a viable deletion mutant. Virology 1989, 171, 189-204. [CrossRef]

14. Pijlman, G.P.; Suhrbier, A.; Khromykh, A.A. Kunjin virus replicons: An RNA-based non-cytopathic viral vector system for protein production, vaccine and gene therapy applications. Expert Opin. Biol. Ther. 2006, 6, 134-145. [CrossRef] [PubMed]

15. De Felipe, F. Skipping the co-expression problem: The new 2A 'CHYSEL' technology. Genet. Vaccines Ther. 2004, 2, 13. [CrossRef]

16. Khromykh, A.A.; Varnavski, A.N.; Westaway, E.G. Encapsidation of the flavivirus Kunjin replicon RNA by using a complementation system providing Kunjin virus structural proteins in trans. J. Virol. 1998, 72, 5967-5977. [CrossRef]

17. Shi, P.Y.; Tilgner, M.; Lo, M.K. Construction and characterization of subgenomic replicons of New York strain of West Nile virus. Virology 2002, 296, 219-233. [CrossRef]

18. Molenkamp, R.; Kooi, E.A.; Lucassen, M.A.; Greve, S.; Thijssen, J.C.; Spaan, W.J.; Bredenbeek, P.J. Yellow fever virus replicons as an expression system for hepatitis C virus structural proteins. J. Virol. 2003, 77, 1644-1648. [CrossRef]

19. Jones, M.; Davidson, A.; Hibbert, L.; Gruenwald, P.; Schlaak, J.; Ball, S.; Foster, G.R.; Jacobs, M. Dengue virus inhibits alpha interferon signaling by reducing STAT2 expression. J. Virol. 2005, 79, 5414-5420. [CrossRef] [PubMed]

20. Gherke, R.; Ecker, M.; Aberle, S.W.; Allison, S.L.; Heinz, F.X.; Mandi, C.W. Incorporation of tick-borne encephalitis virus replicons into virus-like particles by a packaging cell line. J. Virol. 2003, 77, 8924-8933. [CrossRef]

21. Fan, Z.-C.; Dennis, J.C.; Bird, R.C. Bovine viral diarrhea virus is a suitable viral vector for stable expression of heterologous gene when inserted between N(pro) and C genes. Virus Res. 2008, 138, 97-104. [CrossRef]

22. Stetter, P.; Devos, R.; Moser, C.; Tratschin, J.-D.; Hofmann, M. Establishment and application of bicistronic classical swine fever virus genomes for foreign gene expression and complementation of E2 deletion mutants. Virus Res. 2002, 85, 173-185. [CrossRef]

23. Schnell, M.J.; Buonocore, L.; Kretzschmar, E.; Johnson, E.; Rose, J.K. Foreign glycoproteins expressed from recombinant vesicular stomatitis viruses are incorporated efficiently into virus particles. Proc. Natl. Acad. Sci. USA 1996, 93, 11359-11365. [CrossRef] [PubMed]

24. Tani, H.; Morikawa, S.; Matsuura, Y. Development and applications of VSV vectors based on cell tropism. Front. Microbiol. 2012, 2, 272. [CrossRef]

25. Harty, R.N.; Brown, M.E.; Hayes, F.P.; Wright, N.T.; Schnell, M.J. Vaccinia virus-free recovery of vesicular stomatitis virus. J. Mol. Microbiol. Biotechnol. 2001, 3, 513-517.

26. Singh, M.; Cattaneo, R.; Billeter, M.A. A recombinant measles virus expressing hepatitis B surface antigen induces humoral responses in genetically modified mice. J. Virol. 1999, 73, 4823-4828. [CrossRef]

27. Radecke, F.; Spielhofer, P.; Schneider, H.; Kaelin, K.; Huber, M.; Dötsch, C.; Christiansen, G.; Billeter, M.A. Rescue of measles viruses from cloned DNA. EMBO J. 1995, 14, 5773-5784. [CrossRef]

28. Osakada, F.; Callaway, E.M. Design and generation of recombinant rabies virus vectors. Nat. Protoc. 2013, 8, 1583-1601. [CrossRef] [PubMed]

29. Ohara, S.; Inoue, K.; Yamada, M.; Yamawaki, T.; Koganezawa, N.; Tsuttsui, K.; Witter, M.P.; Iijima, T. Dual transneural tracing in the rat entorhoinal-hippocampal circuit by intracerebral injection of recombinant rabies virus vectors. Front. Neuroanat. 2009, 3 , 1-11. [CrossRef] 
30. Ito, N.; Takayama-Ito, M.; Yamada, K.; Hosokawa, J.; Sugiyama, M.; Minamoto, N. Improved recovery of rabies virus from cloned cDNA using a vaccinia virus-free reverse genetics system. Microbiol. Immunol. 2003, 47, 613-617. [CrossRef] [PubMed]

31. Lundstrom, K. Self-amplifying RNA viruses as RNA vaccines. Int. J. Mol. Sci. 2020, 21, 5130. [CrossRef]

32. Chattopadhyay, A.; Aquilar, P.V.; Bopp, N.E.; Yarovinsky, T.O.; Weaver, S.C.; Rose, J.K. A recombinant virus vaccine that protects both against Chikungunya and Zika virus infections. Vaccine 2018, 36, 3894-3900. [CrossRef] [PubMed]

33. Reed, D.S.; Glass, P.J.; Bakken, R.R.; Barth, J.F.; Lind, C.M.; da Silva, L.; Hart, M.K.; Rayner, J.; Alterson, K.; Custer, M.; et al. Combined alphavirus replicon particle vaccine induces durable and cross-protective immune responses against equine encephalitis virus. J. Virol. 2014, 88, 12077-12086. [CrossRef]

34. Tretyakova, I.; Tibbens, A.; Jokinen, J.D.; Johnson, D.M.; Lukashevich, J.S.; Pushko, P. Novel DNA-launched Venezuelan equine encephalitis virus vaccine with rearranged genome. Vaccine 2019, 37, 3317-3325. [CrossRef] [PubMed]

35. Tretyakova, I.; Plante, K.S.; Rossi, S.L.; Lawrence, W.S.; Peel, J.E.; Gudjohnsen, S.; Wang, E.; Mirchandani, D.; Tibbens, A.; Lamichhane, T.N. Venezuelan equine encephalitis vaccine with rearranged genome resists reversion and protects non-human primates from viremia after aerosol challenge. Vaccine 2020, 38, 3378-3386. [CrossRef]

36. Rossi, S.L.; Comer, J.E.; Wang, E.; Azar, S.R.; Lawrence, W.S.; Plante, J.A.; Ramsauer, K.; Schrauf, S.; Weaver, S.C. Immunogenicity and efficacy of a measles virus-vectored chikungunya vaccine in nonhuman primates. J. Infect. Dis. 2019, 220, 735-742. [CrossRef] [PubMed]

37. Safronetz, D.; Mire, C.; Rosenke, K.; Feldmann, F.; Haddock, E.; Geissbert, T.; Feldmann, H. A recombinant vesicular stomatitis virus-based Lassa fever vaccine protects guinea pigs and macaques against challenge with geographically and genetically distinct Lassa viruses. PLoS Negl. Trop. Dis. 2015, 9, e0003736. [CrossRef] [PubMed]

38. Mateo, M.; Reynard, S.; Carnec, X.; Journeaux, A.; Baillet, N.; Schaeffer, J.; Picard, C.; Legras-Lachuer, C.; Allan, R.; Perthame, E.; et al. Vaccines inducing immunity to Lassa fever glycoprotein and nucleoprotein protect macaques after a single shot. Sci. Transl. Med. 2019, 11, eaaw3163. [CrossRef] [PubMed]

39. Bredenbeck, P.J.; Molenkamp, R.; Spaan, W.J.M.; Deubel, V.; Marianneu, P.; Salvato, M.S.; Moshkoff, D.; Zapata, J.; Tikhonov, I.; Patterson, J.; et al. A recombinant Yellow Fever 17D expressing Lassa virus glycoproteins. Virology 2006, 345, 299-304. [CrossRef] [PubMed]

40. Jiang, X.; Dalebout, T.J.; Bredenbeck, P.J.; Carrion, R.J.; Brasky, K.; Patterson, J.; Goicochea, M.; Bryant, J.; Salvato, M.S.; Lukashevich, I.S. Yellow fever 17D-vectored vaccines expressing LASV GP1 and GP2 glycoproteins provide protection against fatal disease in guinea pigs. Vaccine 2011, 29, 1248-1257. [CrossRef]

41. Lukashevich, I.S.; Pushko, P. Vaccine platforms to control Lassa fever. Exp. Rev. Vaccines 2016, 15, 1135-1150. [CrossRef] [PubMed]

42. Pushko, P.; Geisbert, J.; Parker, M.; Jahrling, P.; Smith, J. Individual and bivalent vaccines based on alphavirus replicons protect guinea pigs against infection with Lassa and Ebola virus. J. Virol. 2001, 75, 11677-11685. [CrossRef]

43. Thompson, J.M.; Whitmore, A.C.; Staats, H.F.; Johnston, R.E. Alphavirus replicon particles acting as adjuvants promote CD8+ T cell responses to co-delivered antigen. Vaccine 2008, 26, 4267-4275. [CrossRef]

44. Johnson, D.M.; Jokinen, J.D.; Wang, M.; Pfeiffer, T.; Tretyakova, I.; Carrion, R., Jr.; Griffiths, A.; Pushko, P.; Lukashevich, I.S. Bivalent Junin and Machupo experimental vaccine based on alphavirus RNA replicon vector. Vaccine 2020, 38, 2949-2959. [CrossRef]

45. Pyankov, O.V.; Bodnev, S.A.; Pyankova, O.G.; Solodkyi, V.V.; Pyankov, S.A.; Setoh, Y.X.; Volchokova, V.A.; Suhrbier, A.; Volchikov, V.V.; Agafonov, A.A.; et al. A Kunjin replicon virus-like vaccine provides protection against Ebola virus infection in nonhuman primates. J. Infect. Dis. 2015, 212, S368-S371. [CrossRef]

46. Marzi, A.; Robertson, S.J.; Haddock, E.; Feldmann, F.; Hanley, P.W.; Scott, D.-P.; Strong, J.E.; Kobinger, G.; Best, S.M.; Feldmann, H. VSV-EBOV rapidly protects macaques against infection with the 2014/2015 Ebola virus outbreak strain. Science 2015, 349, 739-742. [CrossRef]

47. Geisbert, T.W.; Feldmann, H. Recombinant vesicular stomatitis virus-based vaccines against Ebola and Marburg infections. J. Infect. Dis. 2011, 204, S1075-S1081. [CrossRef]

48. Herbert, A.S.; Kuehne, A.I.; Barth, J.F.; Ortiz, R.A.; Nichols, D.K.; Zak, S.E.; Stonier, S.W.; Muhammad, M.A.; Bakken, R.R.; Prugar, L.I.; et al. Venezuelan equine encephalitis virus replicon particle vaccine protects nonhuman primates from intramuscular and aerosol challenge with ebolavirus. J. Virol. 2013, 87, 4852-4964. [CrossRef]

49. Khalil, S.M.; Tonkin, D.R.; Mattocks, M.D.; Snead, A.T.; Johnston, R.E.; White, L.J. A tetravalent alphavirus-vector based dengue vaccine provides effective immunity in an early life mouse model. Vaccine 2014, 32, 4068-4074. [CrossRef] [PubMed]

50. Hu, H.M.; Chen, H.W.; Hsiao, Y.; Wu, S.H.; Chung, H.H.; Hsieh, C.H.; Chong, P.; Leng, C.H.; Pan, C.H. The successful induction of T-cell and antibody responses by a recombinant measles virus-vectored tetravalent dengue vaccine provides partial protection against dengue-2 infection. Hum. Vaccines Immunother. 2016, 12, 1678-1689. [CrossRef]

51. Guy, B.; Saville, M.; Lang, J. Development of Sanofi Pasteur tetravalent dengue vaccine. Hum. Vaccines 2010, 6, 696-705. [CrossRef]

52. Ravel, G.; Mantel, N.; Silvano, J.; Rogue, A.; Guy, B.; Jackson, N.; Burdin, N. Biodistribution and safety of a live and attenuated tetravalent dengue vaccine in the cynomolgus monkey. Vaccine 2017, 35, 5918-5923. [CrossRef] [PubMed]

53. Torresi, J.; Ebert, G.; Pellegrini, M. Vaccines licensed and in clinical trials for the prevention of dengue. Hum. Vaccines Immunother. 2017, 13, 1059-1072. [CrossRef] 
54. Erasmus, J.H.; Khandhar, A.P.; Guderian, J.; Granger, B.; Archer, J.; Archer, M.; Cage, E.; Fuerte-Stone, J.; Larson, E.; Lin, S.; et al. A nanostructured lipid carrier for delivery of a replicating viral RNA provides single, low-dose protection against Zika. Mol. Ther. 2018, 26, 2507-2522. [CrossRef]

55. Kurup, D.; Wirblich, C.; Schnell, M.J. Measles-based Zika vaccine induces long-term immunity and requires NS1 antibodies to protect the female reproductive tract in the mouse model of Zika. bioRxiv 2020. [CrossRef]

56. Del Valle, J.R.; Devaux, P.; Hodge, G.; Wegner, N.J.; McChesney, M.B.; Cattaneo, R. A vectored measles virus induces hepatitis B surface antigen antibodies while protecting macaques against virus challenge. J. Virol. 2007, 81, 10597-10605. [CrossRef] [PubMed]

57. Reynolds, T.D.; Buonocore, L.; Rose, N.F.; Rose, J.K.; Robek, M.D. Virus-like vesicle-based therapeutic vaccine vectors for chronic hepatis B virus infection. J. Virol. 2015, 89, 10407-10415. [CrossRef] [PubMed]

58. Lorin, C.; Mollet, L.; Delebecque, F.; Combredet, C.; Hurtrel, B.; Charneau, P.; Brahic, M.; Tangy, F. A single injection of recombinant measles virus vaccine expressing human immunodeficiency virus (HIV) type 1 clade B envelope glycoproteins induces neutralizing antibodies and cellular immune responses to HIV. J. Virol. 2004, 78, 146-157. [CrossRef] [PubMed]

59. Brand, D.; Lemiale, F.; Turbica, I.; Buzelay, L.; Brunet, S.; Barin, F. Comparative analysis of humoral immune responses to HIV type 1 envelope glycoproteins in mice immunized with a DNA vaccine, recombinant Semliki Forest virus RNA, or recombinant Semliki Forest virus particles. AIDS Res. Hum. Retrovir. 1998, 14, 1369-1377. [CrossRef] [PubMed]

60. Giraud, A.; Ataman-Onal, Y.; Battail, N. Generation of monoclonal antibodies to native human immunodeficiency virus type 1 envelope glycoprotein by immunization of mice with naked RNA. J. Virol. Methods 1999, 79, 75-84. [CrossRef]

61. Ajbani, S.P.; Velhal, S.M.; Kadam, R.B.; Patel, V.V.; Lundstrom, K.; Bandivdekar, A.H. Immunogenicity of virus-like Semliki Forest virus replicon particles expressing Indian HIV-1C gag, env and pol RT genes. Immunol. Lett. 2017, 190, 221-232. [CrossRef]

62. Knudsen, M.L.; Ljungberg, K.; Tatoud, R.; Weber, J.; Esteban, M.; Liljestrom, P. Alphavirus replicon DNA expressing HIV antigens is an excellent prime for boosting with recombinant modified vaccinia Ankara (MVA) or with HIV gp140 protein antigen. PLoS ONE 2015, 10, e0117042. [CrossRef]

63. Bogers, W.M.; Oostermeijer, H.; Mooij, P.; Koopman, G.; Verschoor, E.J.; Davis, D.; Ulmer, J.B.; Brito, L.A.; Cu, Y.; Bannerjee, K.; et al. Potent immune responses in rhesus macaques induced by nonviral delivery of self-amplifying RNA vaccine expressing HIV type 1 envelope with a cationic emulsion. J. Infect. Dis. 2015, 211, 947-955. [CrossRef]

64. Ito, T.; Kumagai, T.; Yamaji, Y.; Sawada, A.; Nakayama, T. Recombinant measles AIK-C vaccine strain expressing influenza HA protein. Vaccines 2020, 8, 149. [CrossRef]

65. Ryder, A.B.; Buonocore, L.; Vogel, L.; Nachbagauer, R.; Krammer, F.; Rose, J.K. A viable recombinant rhabdovirus lacking its glycoprotein gene and expressing influenza virus hemagglutinin and neuraminidase is a potent influenza vaccine. J. Virol. 2015, 89, 2820-2830. [CrossRef]

66. Furuyama, W.; Reynolds, P.; Haddock, E.; Meade-White, K.; Le, M.Q.; Kawaoka, Y.; Feldmann, H.; Marzi, A. A single dose of a vesicular stomatitis virus-based influenza vaccine confers rapid protection against $\mathrm{H} 5$ viruses from different clades. NPJ Vaccines 2020, 5, 4. [CrossRef] [PubMed]

67. Schultz-Cherry, S.; Dybing, J.K.; Davis, N.L.; Williamson, C.; Suarez, D.L.; Johnston, R.; Perdue, M.L. Influenza virus (A/HK/156/97) hemagglutinin expressed by an alphavirus replicon system protects against lethal infection with Hong Kong-origin H5N1 viruses. Virology 2000, 278, 55-59. [CrossRef]

68. Fleeton, M.N.; Chen, M.; Berglund, P.; Rhodes, G.; Parker, S.E.; Murphy, M.; Atkins, G.J.; Liljestrom, P. Self-replicative RNA vaccines elicit protection against influenza A virus, respiratory syncytial virus, and a tickborne encephalitis virus. J. Infect. Dis. 2001, 183, 1395-1398. [CrossRef]

69. Vogel, A.B.; Lambert, L.; Kinnear, E.; Busse, D.; Erbar, S.; Reufer, K.C.; Wicke, L.; Perkovic, M.; Beissert, T.; Haas, H.; et al. Self-amplifying RNA vaccines give equivalent protection against influenza to mRNA vaccines but at much lower doses. Mol. Ther. 2018, 26, 446-455. [CrossRef] [PubMed]

70. Krishnavajhala, H.R.; Willimas, J.; Heidner, H. An Influenza A virus vaccine based on an M2e-modified alphavirus. Arch. Virol. 2018, 163, 483-488. [CrossRef] [PubMed]

71. Démoulins, T.; Ruggli, N.; Gerber, M.; Thomann-Harwood, L.J.; Ebensen, T.; Schulze, K.; Guzman, C.A.; McCullough, K.C. Self-amplifying pestivirus replicon RNA encoding influenza virus nucleoprotein and hemagglutinin promote humoral and cellular immune responses in pigs. Front. Immunol. 2021, 11, 622385. [CrossRef] [PubMed]

72. Sheahan, T.; Whitmore, A.; Long, K.; Ferris, M.; Rockx, B.; Funkhouser, B.; Donaldson, E.; Gralinski, L.; Collier, M.; Heise, M.; et al Successful vaccination strategies that protect aged mice from lethal challenge from influenza virus and heterologous severe acute respiratory syndrome coronavirus. J. Virol. 2011, 85, 217-230. [CrossRef] [PubMed]

73. Liu, R.; Wang, J.; Shao, Y.; Wang, X.; Zhang, H.; Shuai, L.; Ge, J.; Wen, Z.; Bu, Z. A recombinant VSV-vectored MERS-CoV vaccine induces neutralizing antibody and $\mathrm{T}$ cell responses in rhesus monkeys after single dose immunization. Antiviral Res. 2018, 150, 30-38. [CrossRef]

74. Hörner, C.; Schürmann, C.; Auste, A.; Ebenig, A.; Muraleedharan, S.; Dinnon, K.H., III; Scholz, T.; Herrmann, M.; Schnierle, B.S.; Baric, R.S.; et al. A highly immunogenic and effective measles virus-based Th1-biased COVID-19 vaccine. Proc. Natl. Acad. Sci. USA 2020, 117, 32657-32666. [CrossRef] [PubMed]

75. Clinical Trial to Evaluate the Safety and Immunogenicity of the COVID-19 Vaccine (COVID-19-101). Available online: https: / / clinicaltrials.gov/ct2/ show / NCT04497298 (accessed on 30 June 2021). 
76. Merck Discontinues Development of SARS-CoV-2/COVID-19 Vaccine Candidates; Continues Development of Two Investigational Therapeutic Candidates. Available online: www.merck.com/news/merck-discontinues-development-of-sars-cov-2-covid-19 -vaccine-candidates-continues-development-of-two-investigational-therapeutic-candidates/ (accessed on 30 June 2021).

77. Case, J.B.; Rothlauf, P.W.; Chen, R.E.; Kafai, N.M.; Fox, J.M.; Smith, B.K.; Shrihari, S.; McCune, B.T.; Harvey, I.B.; Keeler, S.P.; et al. Replication-competent vesicular stomatitis virus vaccine vector protects against SARS-CoV-2-mediated pathogenesis in mice. Cell Host Microbe 2020, 28, 465-474. [CrossRef]

78. Dose Ranging Trial to Assess Safety and Immunogenicity of V590 (COVID-19 Vaccine) in Healthy Adults (V590-001). Available online: https: / / clinicaltrials.gov/ct2/show / NCT04569786 (accessed on 30 June 2021).

79. Merck and IAVI Discontinue Development of COVID-19 Vaccine Candidate V590. Available online: www.iavi.org/ newsresources / press-releases / 2021/merck-and-iavi-discontinue-development-of-covid-19-vaccine-candidate-v590 (accessed on 30 June 2021).

80. Yahalom-Ronen, Y.; Tamir, H.; Melamed, S.; Politi, B.; Shifman, O.; Achdout, H.; Vitner, E.B.; Israeli, O.; Milrot, E.; Stein, D.; et al. A single dose of recombinant VSV- $\Delta$ G-spike provides protection against SARS-CoV-2 challenge. Nat. Commun. 2020, 11, 6402. [CrossRef]

81. Evaluate the Safety, Immunogenicity and Potential Efficacy of an rVSV-SARS-CoV-2-S Vaccine. Available online: https:// clinicaltrials.gov/ct2/show / NCT04608305 (accessed on 30 June 2021).

82. Levin, Y.; Balakirski, N.M.; Caraco, Y.; Ben-Ami, E.; Atsmon, J.; Marcus, H. Ethics and execution of developing a 2nd wave COVID vaccine-Our interim phase I/II VSV-SARS-CoV2 vaccine experience. Vaccine 2021, 39, 2821-2823. [CrossRef]

83. Tao, J.; Li, B.; Shi, Y.; Chen, J.; Zhu, G.; Shen, X.; Liu, H. Attenuated porcine-derived type 2 bovine viral diarrhea virus as vector stably expressing viral gene. J. Virol. Methods 2020, 279, 113842. [CrossRef]

84. McKay, P.F.; Hu, K.; Blakney, A.K.; Samnuan, K.; Brown, J.C.; Penn, R.; Zhou, J.; Bouton, C.R.; Rogers, P.; Polra, K.; et al. Self-amplifying RNA SARS-CoV-2 lipid nanoparticle vaccine candidate induces high neutralizing antibodies in mice. Nat. Commun. 2020, 11, 3523. [CrossRef]

85. Clinical Trial to Assess the Safety of a Coronavirus Vaccine in Healthy Men and Women. Available online: https://doi.org/10.1 186/ISRCTN17072692 (accessed on 30 June 2021).

86. De Alwis, R.; Gan, E.S.; Chen, S.; Leong, Y.S.; Tan, H.C.; Zhang, S.L.; Yau, C.; Low, J.G.H.; Kalimuddin, S.; Matsuda, D.; et al. A single dose of self-transcribing and replicating RNA-based SARS-CoV-2 vaccine produces protective adaptive immunity in mice. Mol. Ther. 2021, 29, 1970-1983. [CrossRef] [PubMed]

87. Scaglione, A.; Opp, S.; Hurtado, A.; Lin, Z.; Pampeno, C.; Noval, M.G.; Thannickal, S.A.; Stappleford, K.A.; Meruelo, D. Combination of a Sindbis-SARS-CoV-2 spike vaccine and $\alpha \mathrm{OX} 40$ antibody elicits protective immunity against SARS-CoV-2 induced disease and potentiates long-term SARS-CoV-2-specific humoral and T-cell immunity. bioRxiv 2021. [CrossRef]

88. Thomas, J.M.; Moen, S.T.; Gnade, B.T.; Vargas-Inchaustegui, D.A.; Foitz, S.M.; Suarez, G.; Heidner, H.W.; König, R.; Chopra, A.K.; Peterson, J.W. Recombinant Sindbis virus vectors designed to express protective antigen of Bacillus anthracis protect animals from anthrax and display synergy with ciprofloxacin. Clin. Vaccine Immunol. 2009, 16, 1696-1699. [CrossRef]

89. Cabrera, A.; Saez, D.; Cespedes, S.; Andrews, E.; Onate, A. Vaccination with recombinant Semliki Forest virus particles expressing translation initiation factor 3 of Brucella abortus induces protective immunity in BALB/c mice. Immunobiology 2009, 214, 467-474. [CrossRef] [PubMed]

90. Andersson, C.; Vasconcelos, N.M.; Sievertzon, M.; Haddad, D.; Liljeqvist, S.; Berglund, P.; Liljestrom, P.; Ahlborg, N.; Ståhl, S.; Berzins, K. Comparative immunization study using RNA and DNA constructs encoding a part of the Plasmodium falciparum antigen Pf332. Scand. J. Immunol. 2001, 54, 117-124. [CrossRef] [PubMed]

91. Tsuji, M.; Bergmann, C.C.; Takita-Sonoda, Y.; Murata, K.; Rodrigues, E.G.; Nussenzweig, R.S.; Zavala, F. Recombinant Sindbis viruses expressing a cytotoxic T-lymphocyte epitope of a malaria parasite or of influenza virus elicit protection against the corresponding pathogen in mice. J. Virol. 1998, 72, 6907-6910. [CrossRef]

92. Savar, N.S.; Vallet, T.; Azizi, M.; Arashkia, A.; Lundstrom, K.; Vignuzzi, M.; Niknam, H.M. Quantitative evaluation of PpSP15LmSTI1 fusion gene expression following transfection with an alphavirus-derived self-amplifying mRNA and conventional DNA vaccine platforms. Mol. Cell. Probes 2021, 59, 101749. [CrossRef] [PubMed]

93. Kelvin, A.A. Outbreak of Chikungunya in the Republic of Congo and the global picture. J. Infect. Dev. Ctries. 2011, 5, 441-444. [CrossRef] [PubMed]

94. Jansen, K.A. The 2005-2007 Chikungunya epidemic in Reunion: Ambiguous etiologies, memories, and meaning-making. Med. Anthropol. 2013, 32, 174-189. [CrossRef]

95. Weaver, S.C.; Salas, R.; Rico-Hesse, R.; Ludwig, G.V.; Oberste, M.S.; Boshell, J.; Tesh, R.B. Re-emergence of epidemic Venezuelan equine encephalomyelitis in South America. VEE Study Group. Lancet 1996, 348, 436-440. [CrossRef]

96. Ramsauer, K.; Schwameis, M.; Firbas, C.; Mullner, M.; Putnak, R.J.; Thomas, S.J.; Despres, P.; Tauber, E.; Jilma, B.; Tangy, F. Immunogenicity, safety, and tolerability of a recombinant measlesvirus-based chikungunya vaccine: A randomised, double-blind, placebo controlled, active-comparator, first-in-man trial. Lancet Infect. Dis. 2015, 15, 519-527. [CrossRef]

97. Reisinger, E.C.; Tschismarov, R.; Beubler, E.; Wiedermann, U.; Firbas, C.; Loebermann, M.; Pfeiffer, A.; Muellner, M.; Tauber, E.; Ramsauer, K. Immunogenicity, safety, and tolerability of the measles-vectored chikungunya virus vaccine MV-CHIK: A doubleblind, randomised, placebo-controlled and active-controlled phase 2 trial. Lancet 2019, 392, 2718-2727. [CrossRef] 
98. A Trial to Evaluate the Optimal Dose of MV-LASV. Available online: https:// clinicaltriasl.gov/ct2/show/NCT4055454 (accessed on 24 June 2021).

99. Henao-Restrepo, A.M.; Longini, I.M.; Egger, M.; Dean, N.E.; Edmunds, W.J.; Camacho, A.; Carroll, M.W.; Doumbia, M.; Draguez, B.; Duraffour, S. Efficacy and effectiveness of an rVSV-vectored vaccine expressing Ebola surface glycoprotein: Interim results from the Guinea ring vaccination cluster-randomised trial. Lancet 2015, 386, 857-866. [CrossRef]

100. Henao-Restrepo, A.M.; Camacho, A.; Longini, I.M.; Watson, C.H.; Edmunds, W.J.; Egger, M.; Carroll, M.W.; Dean, N.E.; Diatta, I.; Doumbia, M.; et al. Efficacy and effectiveness of an rVSV-vectored vaccine in preventing Ebola virus disease: Final results from the Guinea ring vaccination, open-label, cluster-randomised trial (Ebola Ca Suffit!). Lancet 2017, 389, 505-518. [CrossRef]

101. Maxmen, A. Ebola vaccine approved for use in ongoing outbreak. Nature 2017. [CrossRef]

102. Zika-Vaccine Dose Finding Study Regarding Safety, Immunogenicity and Tolerability (V186-001). Available online: https: / / clinicaltrials.gov/ct2/show / NCT02996890 (accessed on 25 June 2021).

103. Safety and Immunogenicity of a Novel Vaccine Formulation. Available online: https:/ / clinicaltrials.gov/ct2/show / NCT04033068 (accessed on 25 June 2021).

104. Wecker, M.; Gilbert, P.; Russell, N.; Hural, J.; Allen, M.; Pensiero, M.; Chulay, J.; Chiu, Y.-L.; Karim, S.S.A.; Burke, D.S.; et al. Phase I safety and immunogenicity evaluations of an alphavirus replicon HIV-1 subtype $\mathrm{C}$ gag vaccine in healthy HIV-1-uninfected adults. Clin. Vaccine Immunol. 2012, 19, 1651-1660. [CrossRef]

105. Subissi, L.; Keita, M.; Mesfin, S.; Rezza, G.; Diallo, B.; Van Gucht, S.; Musa, E.O.; Yoti, Z.; Keita, S.; Djingarey, M.H.; et al. Ebola virus transmission caused by persistently infected survivors of the 2014-2016 outbreak in West Africa. J. Infect. Dis. 2018, 218, S287-S291. [CrossRef]

106. Castanha, P.M.S.; Marques, E.T.A. A glimmer of hope: Recent updates and future challenges in Zika vaccine development. Viruses 2020, 12, 1371. [CrossRef] [PubMed]

107. Roldão, A.; Mellado, M.C.; Castilho, L.R.; Carrondo, M.J.; Alves, P.M. Virus-like particles in vaccine development. Expert Rev. Vaccines 2010, 9, 1149-1176. [CrossRef] [PubMed]

108. Li, J.; Bao, M.; Ge, J.; Ren, S.; Zhou, T.; Qi, F.; Pu, X.; Dou, J. Research progress of therapeutic vaccines for treating chronic hepatitis B. Hum. Vaccines Immunother. 2017, 13, 986-997. [CrossRef]

109. Zoulim, F.; Fournier, C.; Habersetzer, F.; Sprinzl, M.; Pol, S.; Coffin, C.S.; Leroy, V.; Ma, M.; Wedemeyer, H.; Lohse, A.W.; et al. Safety and immunogenicity of the therapeutic vaccine TG1050 in chronic hepatitis B patients: A phase $1 \mathrm{~b}$ placebo-controlled trial. Hum. Vaccines Immunother. 2020, 16, 388-399. [CrossRef] [PubMed]

110. Melo, M.; Porter, E.; Zhang, Y.; Silva, M.; Li, N.; Dobosh, B.; Liquori, A.; Skog, P.; Landais, E.; Menis, S. Immunogenicity of RNA Replicons Encoding HIV Env Immunogens Designed for Self-Assembly into Nanoparticles. Mol. Ther. 2019, 27, 2080-2090. [CrossRef] [PubMed]

111. Lamb, Y.N. BNT162b2 mRNA COVID-19 vaccine: First approval. Drugs 2021, 81, 495-501. [CrossRef]

112. Oliver, S.E.; Gargano, J.W.; Marin, M.; Wallace, M.; Curran, K.G.; Chamberland, M.; McClung, N.; Campos-Outcalt, D.; Morgan, R.L.; Mbaeyi, L.; et al. The advisory committee on immunization practices' interim recommendation for use of moderna COVID-19 vaccine-United States, December 2020. MMWR Morb. Mortal. Wkly Rep. 2021, 69, 1653-1656. [CrossRef]

113. Tseng, J.-C.; Levin, B.; Hurtado, A.; Yee, H.; De Castro, I.P.; Jimenez, M.; Shamamian, P.; Jin, R.; Novick, R.; Pellicer, A.; et al. Systemic tumor targeting and killing by Sindbis viral vectors. Nat. Biotechnol. 2004, 22, 70-77. [CrossRef] [PubMed]

114. Fukuhara, H.; Ino, Y.; Todo, T. Oncolytic virus therapy: A new era of cancer treatment at dawn. Cancer Sci. 2016, 107, 1373-1379. [CrossRef] [PubMed]

115. Zamarin, D.; Palese, P. Oncolytic Newcastle disease virus for cancer therapy: Old challenges and new directions. Future Microbiol. 2012, 7, 347-367. [CrossRef] [PubMed]

116. Aref, S.; Bailey, K.; Fielding, A. Measles to the rescue: A review of oncolytic measles virus. Viruses 2016, 8, 294. [CrossRef] [PubMed]

117. Ebert, O.; Shinozaki, K.; Huang, T.-G.; Savontaus, M.J.; Garcia-Sastre, A.; Woo, S.L.C. Oncolytic vesicular stomatitis virus for treatment of orthotopic hepatocellular carcinoma in immune-competent rats. Cancer Res. 2003, 63, 3605-3611. [PubMed]

118. Zhang, J.; Liu, Y.; Tan, J.; Zhang, Y.; Wong, C.-W.; Lin, Z.; Liu, X.; Sander, M.; Yang, X.; Lian, L.; et al. Necroptotic virotherapy of oncolytic alphavirus M1 cooperated with Doxorubicin displays promising therapeutic efficacy in TNBC. Oncogene 2021, 40, 4783-4795. [CrossRef]

119. Yamanaka, R.; Zullo, S.A.; Ramsey, J.; Onodera, M.; Tanaka, R.; Blaese, M. Induction of therapeutic antitumor anti-angiogenesis by intratumoral injection of genetically engineered endostatin-producing Semliki Forest virus. Cancer Gene Ther. 2001, 8, 796-802. [CrossRef]

120. Yamanaka, R.; Tsuchiya, N.; Yajima, N.; Honma, J.; Hasegawa, H.; Tanaka, R.; Ramsey, J.; Blaese, R.M.; Xanthopoulos, K.G. Induction of an antitumor immunological response by an intratumoral injection of dendritic cells pulsed with genetically engineered Semliki Forest virus to produce interleukin-18 combined with the systemic administration of interleukin-12. J. Neurosurg. 2003, 99, 746-753. [CrossRef]

121. Yamanaka, R.; Xanthopoulos, K.G. Induction of antigen-specific immune responses against malignant brain tumors by intramuscular injection of sindbis DNA encoding gp100 and IL-18. DNA Cell. Biol. 2005, 24, 317-324. [CrossRef]

122. Zhang, X.; Mao, G.; Van den Pol, A.N. Chikungunya-vesicular stomatitis chimeric virus targets and eliminates brain tumors. Virology 2018, 522, 244-259. [CrossRef] 
123. Allen, C.; Opyrchal, M.; Aderca, I.; Schroeder, M.A.; Sarkaria, J.N.; Domingo, E.; Federspiel, M.J.; Galanis, E. Oncolytic measles virus strains have a significant antitumor activity against glioma stem cells. Gene Ther. 2013, 2, 444-449. [CrossRef]

124. Heikkilä, J.E.; Vähä-Koskela, M.J.; Ruotsalainen, J.J.; Martikainen, M.W.; Stanford, M.M.; McCart, J.A.; Bell, J.C.; Hinkkanen, A.E. Intravenously administered alphavirus vector VA7 eradicates orthotopic human glioma xenografts in nude mice. PLoS ONE 2010, 5, e8603. [CrossRef]

125. Martikainen, M.; Niittykoski, M.; von und zu Frauenberg, M.; Immonen, A.; Koponen, S. MicroRNA attenuated clone of virulent Semliki Forest virus overcomes antiviral type I interferon in resistant mouse CT-2A glioma. J. Virol. 2015, 89, 10637-10647. [CrossRef] [PubMed]

126. Wang, X.; Wang, J.P.; Rao, X.M.; Price, J.E.; Zhou, H.S.; Lachman, L.B. Prime-boost vaccination with plasmid and adenovirus gene vaccines control HER2/neu+ metastatic breast cancer in mice. Breast Cancer Res. 2005, 7, R580-R588. [CrossRef]

127. Lachman, L.B.; Rao, X.M.; Kremer, R.H.; Ozpolat, B.; Kirjakova, G.; Price, J.E. DNA vaccination against neu reduces breast cancer incidence and metastasis in mice. Cancer Gene Ther. 2001, 8, 259-268. [CrossRef]

128. Kramer, M.G.; Masner, M.; Casales, E.; Moreno, M.; Smerdou, C.; Chabalgoity, J.A. Neoadjuvant administration of Semliki Forest virus expressing interleukin-12 combined with attenuated Salmonella eradicates breast cancer metastasis and achieves long-term survival in immunocompetent mice. BMC Cancer 2015, 15, 620. [CrossRef] [PubMed]

129. A Study to Evaluate Concurrent VRP-HER2 Vaccination and Pembrolizumab for Patients with Breast Cancer. Available online: ClinicalTrials.govNCT03632941 (accessed on 2 July 2021).

130. Sugiyama, T.; Yoneda, M.; Kuraishi, T.; Hattori, S.; Inoue, Y.; Sato, H.; Kai, C. Measles virus selectively blind to signaling lymphocyte activation molecule as a novel oncolytic virus for breast cancer treatment. Gene Ther. 2013, 20, 338-347. [CrossRef]

131. Cantarella, G.; Liniger, M.; Zuniga, A.; Schiller, J.T.; Billeter, M.; Naim, H.Y.; Glueck, R. Recombinant measles virus-HPV vaccine candidates for prevention of cervical carcinoma. Vaccine 2009, 27, 3386-3390. [CrossRef] [PubMed]

132. Gupta, G.; Giannino, V.; Rishi, N.; Glueck, R. Immunogenicity of next-generation HPV vaccines in non-human primates: Measles-vectored HPV vaccine versus Pichia pastoris recombinant protein vaccine. Vaccine 2016, 34, 4724-4731. [CrossRef] [PubMed]

133. Brandsma, J.L.; Shylankevich, M.; Su, Y.; Roberts, A.; Rose, J.K.; Zelterman, D.; Buonocore, L. Vesicular stomatitis virus-based therapeutic vaccination targeted to the E1, E2, E6, and E7 proteins of cottontail rabbit papillomavirus. J. Virol. 2007, 81, 5749-5758. [CrossRef]

134. Liao, J.B.; Publicover, J.; Rose, J.K.; DiMaio, D. Single-dose, therapeutic vaccination of mice with vesicular stomatitis virus expressing human papillomavirus type 16 E7 protein. Clin. Vaccine Immunol. 2008, 15, 817-824. [CrossRef] [PubMed]

135. Velders, M.P.; McElhiney, S.; Cassetti, M.C.; Eiben, G.L.; Higgins, T.; Kovacs, G.R. Eradication of established tumors by vaccination with Venezuelan equine encephalitis virus replicon particles delivering human papillomavirus 16 E7 RNA. Cancer Res. 2001, 61, 7861-7867. [PubMed]

136. Daemen, T.; Riezebos-Brilman, A.; Bungener, L.; Regts, J.; Dontje, B.; Wilschut, J. Eradication of established HPV16-transformed tumours after immunisation with recombinant Semliki Forest virus expressing a fusion protein of E6 and E7. Vaccine 2003, 21, 1082-1088. [CrossRef]

137. Van de Wall, S.; Ljungberg, K.; Ip, P.P.; Boerma, A.; Knudsen, M.L.; Nijman, H.W.; Liljeström, P.; Daemen, T. Potent therapeutic efficacy of an alphavirus replicon DNA vaccine expressing human papilloma virus E6 and E7 antigens. Oncoimmunology 2018, 7 , e1487913. [CrossRef]

138. Hoang-Le, D.; Smeenk, L.; Anraku, I.; Pijlman, G.P.; Wang, X.P.; De Vrij, J. A Kunjin replicon vector encoding granulocyte macrophage colony-stimulating factor for intra-tumoral gene therapy. Gene Ther. 2009, 16, 190-199. [CrossRef] [PubMed]

139. Lyons, J.A.; Sheahan, B.J.; Galbraith, S.E. Inhibition of angiogenesis by a Semliki Forest virus vector expressing VEGFR-2 reduces tumour growth and metastasis in mice. Gene Ther. 2007, 14, 503-513. [CrossRef]

140. Ying, H.; Zaks, T.Z.; Wang, R.-F.; Irvine, K.R.; Kammula, U.S.; Marincola, F.M. Cancer therapy using a self-replicating RNA vaccine. Nat. Med. 1999, 5, 823-827. [CrossRef]

141. Grossardt, C.; Engeland, C.E.; Bossow, S.; Halama, N.; Zaoui, K.; Leber, M.F.; Springfeld, C.; Jaeger, D.; Von Kalle, C.; Ungerechts, G. Granulocyte-macrophage colony-stimulating factor-armed oncolytic measles virus is an effective therapeutic cancer vaccine. Hum. Gene Ther. 2013, 24, 644-654. [CrossRef]

142. Murphy, A.M.; Morris-Downes, M.M.; Sheahan, B.J.; Atkins, G.J. Inhibition of human lung carcinoma cell growth by apoptosis induction using Semliki Forest virus recombinant particles. Gene Ther. 2000, 7, 1477-1482. [CrossRef] [PubMed]

143. Määttä, A.M.; Mäkinen, K.; Ketola, A.; Liimatainen, T.; Yongabi, F.N.; Vähä-Koskela, M. Replication competent Semliki Forest virus prolongs survival in experimental lung cancer. Int. J. Cancer 2008, 123, 1704-1711. [CrossRef]

144. Granot, T.; Yamanashi, Y.; Meruelo, D. Sindbis viral vectors transiently deliver tumor-associated antigens to lymph nodes and elicit diversified antitumor CD8+ T-cell immunity. Mol. Ther. 2014, 22, 112-122. [CrossRef] [PubMed]

145. Zhao, D.; Chen, P.; Yang, H.; Wu, Y.; Zeng, X.; Zhao, Y.; Wen, Y.; Zhao, X.; Liu, X.; Wei, Y.; et al. Live attenuated measles virus vaccine induces apoptosis and promotes tumor regression in lung cancer. Oncol. Rep. 2013, 29, 199-204. [CrossRef] [PubMed]

146. Boisgerault, N.; Guillerme, J.B.; Pouliquen, D.; Mesel-Lemoine, M.; Achard, C.; Combredet, C.; Fonteneau, J.-F.; Tangy, F.; Grégoire, M. Natural oncolytic activity of live-attenuated measles virus against human lung and colorectal adenocarcinomas. Biomed. Res. Int. 2013, 2013, 387362. [CrossRef] [PubMed] 
147. Patel, M.R.; Jacobson, B.A.; Belgum, H.; Raza, A.; Sadiq, A.; Drees, J.; Wang, H.; Jay-Dixon, J.; Etchison, R.; Federspiel, M.J.; et al. Measles vaccine strains for virotherapy of non-small cell lung carcinoma. J. Thorac. Oncol. 2014, 9, 1101-1110. [CrossRef]

148. Patel, M.R.; Jacobson, B.A.; Ji, Y.; Drees, J.; Tang, S.; Xiong, K. Vesicular stomatitis virus expressing interferon- $\beta$ is oncolytic and promotes antitumor immune responses in a syngeneic murine model of non-small cell lung cancer. Oncotarget 2015, 6, 33165-33177. [CrossRef]

149. McAllister, A.; Arbetman, A.E.; Mandl, S.; Pena-Rossi, C.; Andino, R. Recombinant yellow fever viruses are effective therapeutic vaccines for treatment of murine solid tumors and pulmonary metastases. J. Virol. 2000, 74, 9197-9205. [CrossRef]

150. Avogadri, F.; Merghoub, T.; Maughan, M.F.; Hirschhorn-Cymerman, D.; Morris, J.; Ritter, E. Alphavirus replicon particles expressing TRP-2 provide potent therapeutic effect on melanoma through activation of humoral and cellular immunity. PLoS ONE 2010, 5, e12670. [CrossRef]

151. Avogadri, F.; Zappasodi, R.; Yang, A.; Budhu, S.; Malandro, N.; Hisrchhorn-Cymerman, D. Combination of alphavirus replicon particle-based vaccination with immunomodulatory antibodies: Therapeutic activity in the B16 melanoma mouse model and immune correlates. Cancer Immunol. Res. 2014, 2, 448-458. [CrossRef]

152. Yin, X.; Wang, W.; Zhu, X.; Wang, Y.; Wu, S.; Wang, Z. Synergistic antitumor efficacy of combined DNA vaccines targeting tumor cells and angiogenesis. Biochem. Biophys. Res. Comm. 2015, 465, 239-244. [CrossRef]

153. Ammour, Y.; Ryabaya, O.; Shchetinina, Y.; Prokofeva, E.; Gavrilova, M.; Khochenkov, D.; Vorobyev, D.; Faizuloev, E.; Shohin, I.; Zverev, V.V.; et al. The susceptibility of human melanoma cells to infection with the Leningrad-16 vaccine strain of measles virus. Viruses 2020, 12, 173. [CrossRef]

154. Kimpel, J.; Urbiola, C.; Koske, I.; Tober, R.; Banki, Z.; Wollmann, G. The Oncolytic virus VSV-GP is effective against malignant melanoma. Viruses 2018, 10, 108. [CrossRef] [PubMed]

155. Dold, C.; Rodriguez Urbiola, C.; Wollmann, G.; Egerer, L.; Muik, A.; Bellmann, L.; Fiegl, H.; Marth, C.; Kimpel, J.; Von Laer, D. Application of interferon modulators to overcome partial resistance to ovarian cancers to VSV-GP oncolytic viral therapy. Mol. Ther. Oncolytics 2016, 3, 16021. [CrossRef]

156. Hasegawa, K.; Nakamura, T.; Harvey, M.; Ikeda, Y.; Oberg, A.; Figini, M.; Canevari, S.; Hartmann, L.C.; Peng, K.-W. The use of a tropism-modified measles virus in folate receptor-targeted virotherapy of ovarian cancer. Clin. Cancer Res. 2006, 12, 6170-6178. [CrossRef] [PubMed]

157. Hasegawa, K.; Pham, L.; O'Connor, M.K.; Federspiel, M.J.; Russel, S.J.; Peng, K.-W. Dual therapy of ovarian cancer using measles viruses expressing carcinoembryonic antigen and sodium iodide symporter. Clin. Cancer Res. 2006, 12, 1868-1875. [CrossRef] [PubMed]

158. Granot, T.; Meruelo, D. The role of natural killer cells in combinatorial anti-cancer therapy using Sindbis viral vector and irinotecan. Cancer Gene Ther. 2012, 19, 588-591. [CrossRef]

159. Zhang, Y.Q.; Tsai, Y.C.; Monie, A.; Wu, T.C.; Hung, C.F. Enhancing the therapeutic effect against ovarian cancer through a combination of viral oncolysis and antigen-specific immunotherapy. Mol. Ther. 2010, 18, 692-699. [CrossRef]

160. Murphy, A.M.; Besmer, D.M.; Moerdyk-Schauwecker, M.; Moestl, N.; Ornelles, D.A.; Mukherjee, P. Vesicular stomatitis virus as an oncolytic agent against pancreatic ductal adenocarcinoma. J. Virol. 2012, 86, 3073-3087. [CrossRef]

161. Hastle, E.; Besmer, D.M.; Shah, N.R.; Murphy, A.M.; Moredyk-Schauwecker, M.; Molestina, C.; Roy, L.R.; Curry, J.M.; Mukherjee, P.; Grdzelishvili, V.Z. Oncolytic vesicular stomatitis virus in an immunocompetent model of MUC1-positive or MUC1-nulll pancreatic ductal adenocarcinoma. J. Virol. 2013, 87, 10283-10294. [CrossRef]

162. Awano, M.; Fuijyki, T.; Shoji, K.; Amagai, Y.; Murakami, Y.; Furukawa, Y.; Sato, H.; Yoneda, M.; Kai, C. Measles virus selectively blind to signaling lymphocyte activity molecule has oncolytic efficacy against nectin-4 expressing pancreatic cells. Cancer Sci. 2016, 107, 1647-1652. [CrossRef]

163. Msaouel, P.; Iankov, I.D.; Allen, C.; Morris, J.C.; von Messling, V.; Cattaneo, R. Engineered measles virus as a novel oncolytic therapy against prostate cancer. Prostate 2009, 69, 82-91. [CrossRef]

164. Son, H.A.; Zhang, L.; Cuong, B.K.; Van Tong, H.; Cuong, L.D.; Hang, N.T.; Nhung, H.T.M.; Yamamoto, N.; Toan, N.L. Combination of vaccine-strain measles and mumps viruses enhances oncolytic activity against human solid malignancies. Cancer Investig. 2018, 7, 106-117. [CrossRef]

165. Zhao, X.; Huang, S.; Luo, H.; Wan, X.; Gui, Y.; Li, J.; Wu, D. Evaluation of vesicular stomatitis virus mutant as an oncolytic agent against prostate cancer. Int. J. Clin. Exp. Med. 2014, 7, 1204-1213.

166. Urbiola, C.; Santer, F.R.; Petersson, M.; van der Pluijm, G.; Horninger, W.; Erlmann, P. Oncolytic activity of the rhabdovirus VSV-GP against prostate cancer. Int. J. Cancer 2018, 143, 1786-1796. [CrossRef]

167. Durso, R.J.; Andjelic, S.; Gardner, J.P.; Margitich, D.J.; Donovan, G.P.; Arrigale, R.R. A novel alphavirus vaccine encoding prostate-specific membrane antigen elicits potent cellular and humoral immune responses. Clin. Cancer Res. 2007, 13, 3999-4008. [CrossRef] [PubMed]

168. Garcia-Hernandez, M.L.; Gray, A.; Hubby, B.; Kast, W.M. In vivo effects of vaccination with six-transmembrane epithelial antigen of the prostate: A candidate antigen for treating prostate cancer. Cancer Res. 2007, 67, 1344-1351. [CrossRef]

169. Garcia-Hernandez, M.L.; Gray, A.; Hubby, B.; Klinger, O.J.; Kast, W.M. Prostate stem cell antigen vaccination induces a long-term protective immune response against prostate cancer in the absence of autoimmunity. Cancer Res. 2008, 68, 861-869. [CrossRef] [PubMed] 
170. Crosby, E.J.; Gwin, W.; Blackwell, K.; Marcom, P.K.; Chang, S.; Maecker, H.T.; Broadwater, G.; Hyslop, T.M.; Kim, S.; Rogatko, A.; et al. Vaccine-induced memory CD8(+) T cells provide clinical benefit in HER2 expressing breast cancer: A mouse to human translational study. Clin. Cancer Res. 2019, 25, 2725-2736. [CrossRef]

171. Komdeur, F.L.; Singh, A.; Van de Wall, S.; Meulenberg, J.J.M.; Boerma, A.; Hoogeboom, B.N.; Paijens, S.T.; Oyarce, C.; de Bruyn, M.; Schuuring, E.; et al. First-in-human phase I clinical trial of an SFVBased RNA replicon cancer vaccine against HPV-induced cancers. Mol. Ther. 2021, 29, 611-625. [CrossRef] [PubMed]

172. Crosby, E.J.; Hobeika, A.C.; Niedzweicki, D.; Rushing, C.; Hsu, D.; Berglund, P.; Smith, J.; Osada, T.; Gwin, W.R., III; Hartman, Z.C.; et al. Long-term survival of patients with stage III colon cancer treated with VRP-CEA(6D), an alphavirus vector that increases the CD8+ effector memory $\mathrm{T}$ cell to Treg ration. J. Immunother. Cancer 2020, 8, e001662. [CrossRef]

173. Galanis, E.; Hartmann, L.C.; Cliby, W.A.; Long, H.J.; Peethambaram, P.P.; Barrette, B.A.; Kaur, J.S.; Haluska, P.J., Jr.; Aderca, I.; Zollman, P.J.; et al. Phase I trial of intraperitoneal administration of an oncolytic measles virus strain engineered to express carcinoembryonic antigen for recurrent ovarian cancer. Cancer Res. 2010, 70, 875-882. [CrossRef]

174. Morse, M.A.; Hobelka, A.C.; Osada, T.; Berglund, P.; Hubby, B.; Negri, S. An alphavirus vector overcomes the presence of neutralizing antibodies and elevated numbers of Tregs to induce immune responses in humans with advanced cancer. J. Clin. Investig. 2010, 120, 3234-3241. [CrossRef]

175. Griifin, D.E. Neurotropic alphaviruses. In Neurotropic Viral Infections; Reiss, C., Ed.; Springer: Cham, Switzerland, 2016; pp. 175-204.

176. Vasilevska, J.; Skrastina, D.; Spunde, K.; Garoff, H.; Kozlovska, T.; Zajakina, A. Semliki Forest virus biodistribution in tumor-free and 4T1 mammary tumor-bearing mice: A comparison of transgene delivery by recombinant virus particles and naked RNA replicon. Cancer Gene Ther. 2012, 19, 579-587. [CrossRef] [PubMed]

177. FDA Licenses New Vaccine for Prevention of Cervical Cancer and Other Diseases in Females Caused by Human Papillomavirus (Press release). U.S. Food and Drug Administration (FDA). 8 June 2006. Archived from the Original on 19 October 2009. Available online: http:/ / www.fda.gov/NewsEvents/Newsroom/PressAnnouncements/2006/ucm108666.htm (accessed on 2 July 2021).

178. Hromic-Jahjefendic, A.; Lundstrom, K. Viral vector-based melanoma gene therapy. Biomedicines 2020, 8, 60. [CrossRef]

179. Slovin, S.F.; Kehoe, M.; Durso, R.; Fernandez, C.; Olson, W.; Gao, J.P. A phase I dose escalation trial of vaccine replicon particles (VRP) expressing prostate-specific membrane antigen (PSMA) in subjects with prostate cancer. Vaccine 2013, 31, 943-949. [CrossRef] [PubMed]

180. Berglund, P.; Sjöberg, M.; Garoff, H.; Atkins, G.J.; Sheahan, B.J.; Liljeström, P. Semliki Forest virus expression system: Production of conditionally infectious recombinant particles. Biotechnology 1993, 11, 916-920. [CrossRef] [PubMed]

181. Smerdou, C.; Liljeström, P. Two-helper system for production of recombinant Semliki Forest virus particles. J. Virol. 1999, 73, 1092-1098. [CrossRef] [PubMed] 